\title{
Sağlık Alanında Kullanılan Derin Öğrenme Yöntemleri
}

\author{
Umut Kaya $^{1 *}$, Atınç Yılmaz ${ }^{2}$, Yalım Dikmen ${ }^{3}$ \\ ${ }^{1 *}$ İzmir Kavram Meslek Yüksekokulu, Bilgisayar Teknolojileri Bölümü, Bilgisayar Programcıllı̆ı̆, İstanbul, Türkiye (ORCID: 0000-0002-1410-3444) \\ ${ }^{2}$ Beykent Üniversitesi, Mimarlık ve Mühendislik Fakültesi, Bilgisayar Mühendisliği, İstanbul, Türkiye (ORCID: 0000-0003-0038-7519) \\ ${ }^{3}$ İstanbul Üniversitesi-Cerrahpaşa, Cerrahpaşa Tıp Fakültesi, Anesteziyoloji ve Reanimasyon Anabilim Dali, İstanbul, Türkiye (ORCID: 0000-0002-3122-5099)
}

(İlk Geliş Tarihi 1 Haziran 2019 ve Kabul Tarihi 30 Temmuz 2019)

(DOI: 10.31590/ejosat.573248)

ATIF/REFERENCE: Kaya, U., Yılmaz, A. \& Dikmen, Y. (2019). Sağlık Alanında Kullanılan Derin Öğrenme Yöntemleri. Avrupa Bilim ve Teknoloji Dergisi, (16), 792-808.

$\ddot{O} \mathbf{z}$

Uzun süreli tedavi gerektiren kanser ve benzeri hastalıklara yakalanan hastaların ölüm riski yüksektir. Bu riski azaltmak ve hastanın yaşam süresini uzatmak için tıpta, teknolojideki gelişmelerin de kullanıldığı çalışmalar bulunmaktadır. Bu çalışmalarda hastalığın tedavisi için çok önemli olan erken tanı yöntemlerine odaklanılmıştır. Yapay zekâ, makinelerin insan beyninin çalışmasını taklit ederek karar verme ve tahmin etme gibi çözülmesi zor olan problemlerin çözümüne imkân tanıyan bir bilim dalıdır. Yapay zekânın bir alt dalı olan makine öğrenmesi ise kodlanmış olan hazır talimatları kullanarak çözüm üretmek yerine; örneklerden öğrenerek, görüntü, resim ve ses tanıma gibi birçok zor probleme çözüm getirmektedir. Son yıllarda birçok alanda kullanılan makine öğrenmesinin, hastalıkların erken teşhisinde kullanılabilme potansiyeli de bulunmaktadır. Konu ile ilgili yapılan çalışmalar özellikle makine öğrenmesinin bir alt dalı olan derin öğrenme yöntemlerine odaklanmıştır. Bu çalışmanın amacı sağlık alanında uygulanan derin öğrenme yöntemlerinin çalışma prensiplerini ve hangi hastalıklarda kullanıldığını, ilgili literatür ışığında ortaya koymaktır. Bu çalışmanın sonucunda, hastalığın teşhisinde kullanılan verilere uygun derin öğrenme yönteminin tercih edilmesinin, hastalığa erken tanı konma başarısını arttıracağı düşünülmektedir.

Anahtar Kelimeler: Erken tanı, yapay zekâ, makine öğrenmesi, derin öğrenme

\section{Deep Learning Methods used in the field of Health}

\begin{abstract}
Patients with cancer and similar diseases requiring long-term treatment have a high risk of death. In order to reduce this risk and extend the life expectancy of the patient, there are studies that use advances in technology in medicine. These studies focused on early diagnosis methods which are very important for the treatment of the disease. Artificial intelligence is a branch of science that allows machines to solve problems that are difficult to solve, such as making decisions and predictions, by imitating the workings of the human brain. Machine learning, which is a sub-branch of artificial intelligence, instead of producing solutions by using ready-coded instructions; learning from examples, it provides solutions to many difficult problems such as image, picture and voice recognition. Machine learning, which has been used in many areas in recent years, has the potential to be used in early diagnosis of diseases. Studies on the subject have focused on deep learning methods, which is a sub-branch of machine learning. The aim of this study is to reveal the working principles of deep learning methods applied in the field of health and in which diseases they are used in the light of the related literature. As a result of this study, it is thought that choosing a deep learning method appropriate to the data used in the diagnosis of the disease will increase the success of early diagnosis of the disease.
\end{abstract}

Keywords: Early diagnosis, artificial intelligence, machine learning, deep learning

\footnotetext{
* Sorumlu Yazar: İzmir Kavram Meslek Yüksekokulu, Bilgisayar Teknolojileri Bölümü, Bilgisayar Programcıllğı, İstanbul, Türkiye, ORCID: 00000002-1410-3444, m.umutkaya@gmail.com
} 


\section{Giriş}

Uzun süreli tedavi gerektiren hastalıklarda yoğun bakıma ihtiyaç duyan hastalar ayakta tedavi görenlere göre hem daha maliyetli hem de ölüm riski daha yüksek hastalardır. Bu maliyet gün geçtikçe de artmaktadır. Artan bu maliyetler ve ölümler nedeniyle WHO (Dünya Sağlık Örgütü) hastalıklara yakalanmadan önce hastalıktan korunma yöntemlerine dikkat çekmeye çalışmıştır. Bilinçlenmeye rağmen, genetik, çevresel ve diğer faktörler nedeniyle ortaya çıkan hastalık riskine karşı belirli dönemlerde doktor kontrolünden geçmek kaçınılmazdır. Bu kontroller sonucunda elde edilen bulgular hastalıklara yakalanma riskini ortaya koymakta; riskin büyüklüğü ve ortaya çıma süresinin kısaltılması da erken tanı ile olmaktadır.

Yapılan çalışmalara göre makine öğrenmesi, hastalıkların erken tanısında en çok kullanılan yöntemlerdendir. İnsan yaşamını birçok alanda kolaylaştıran bilgisayarların, günümüzde insan gibi düşünmesini sağlamak için yapılan çalışmalar, makine öğrenimini ortaya çıkarmıştır. İnsan zekâsını taklit etmeye yönelik olan bu öğrenme şekli, yapay zekâ olarak adlandırılmaktadır. Teknolojik anlamda ortaya çıkan bu gelişme, hastalıkların tedavisinde önemli bir rol oynamaktadır. Ancak insanlar ve makineler evrim geçirirken, hastalıklara neden olan aktörler de evrimleşmektedir ve hastalıkları önlemede ya da tedavisinde kullanılan ilaçlara karşı bağışıklık kazanmaktadırlar.

Sağlık alanında uygulanan derin öğrenmenme yöntemlerinin incelendiği bu çalışmada, derin öğrenmenin tanımı yapılmış ve derin öğrenme yöntemleri açıklanarak, bu yöntemlerin kullanıldı̆̆ı alanlardan bahsedilmiştir. Daha sonra sağlık alanında kullanılan derin öğrenme yöntemleri tanıtılarak, bu yöntemlerin sağlık alanındaki uygulamalarına değinilmiştir. Sonuç bölümünde ise bu yöntemlerin başarıları tartışılmıştır.

\section{Derin Öğrenme}

İnsan beyni duyu organları ile elde etmiş olduğu verileri daha önce tecrübe etmiş oldukları örnekler ile karşılaştırarak bunu bilgiye dönüştürür. Elde edilen bilgi insanın anlık karar vermesinde kullanılabilir ya da daha sonraki alacağı kararlarda etkili olabilir. Karmaşık bir yapıya sahip olan beynin karar vermesini sağlayan yapının matematiksel olarak ifade edilmeye çalışılması ile ortaya çıkan yapay zekâ kavramı, beynin çalışmasını anlamaya çalışmakla başlamıştır. İnsandaki sinir hücrelerini taklit ederek makinelerin öğrenme sürecini başlatan yapay sinir ağları daha çok veri ile daha karmaşı problemlerin çözümü için evrimleşerek 21. yüzyılda derin öğrenmeye evirilmiştir.

Derin öğrenme; nesne tanıma, konuşma tanıma, doğal dil işleme gibi alanlarda çok katmanlı yapay sinir ağlarını kullanan bir yapay zekâ yöntemi olup makine öğrenmesinin çeşitlerinden biridir. Derin öğrenme, geleneksel makine öğrenmesi yöntemlerinden farklı olarak kodlanmış kurallar ile öğrenmek yerine; resim, video, ses ve metinlere ait verilerin simgelerinden otomatik olarak öğrenebilmektedirler [1]. Esnek yapıda olduklarından, ham resim ya da metin verisinden de öğrenebilmekte ve verinin büyüklüğüne göre tahmin doğrulukları artabilmektedir. Bununla birlikte derin öğrenme, örnekler üzerinden öğrenme işlemini gerçekleştirmektedir [2]. Makinenin çözmesi istenen bir problem için kural setleri kullanarak çözüme ulaşmak yerine örnekleri değerlendirerek probleme çözüm getirmesini sağlayan bir model verilmesi yeterlidir. Problemin çözümündeki hatayı düzeltebilmesi için de basit bir komut listesi verilerek makinenin öğrenme işlemini gerçekleştirmesi beklenmektedir. Model seçimi, problemin çözümünde etkindir. Probleme uygun olarak belirlenecek model, problemin çözümüne daha fazla katkıda bulunacaktır. Derin öğrenme kavramı ilk kez 2006 yılında Hinton tarafından çok katmanlı yapay sinir ağlarının daha verimli eğitilebileceğinin öne sürülmesiyle ortaya çıkmıştır.

\subsection{Derin Öğrenme Yöntemleri}

Bu bölümde Derin Sinir Ağları (DSA), Derin Oto-Kodlayıcılar (DOK), Derin İnanç Ağları (DİA), Derin Boltzmann Makinesi (DBM), Yinelemeli Sinir Ağları (YİSA) ve Evrişimli Sinir Ağları (ESA) yöntemlerinden bahsedilmiştir.

\subsubsection{Derin Sinir Ağları (DSA)}

Derin ağ yapısı genellikle sınıflandırma ve regresyon için kullanılmaktadır. İkiden fazla gizli katmana sahip olan yapıdır (Şekil 1). Karmaşık hipotezlerin tanımlanmasını sağlar. Genellikle birçok alanda kullanımında başarılı olunmuştur. Eğitim önemlidir. Çünkü hata değerleri birkaç katman geri yayıllırlarsa çok düşük değerlere dönüşmektedirler. Öğrenme süreci zaman alabilmektedir.

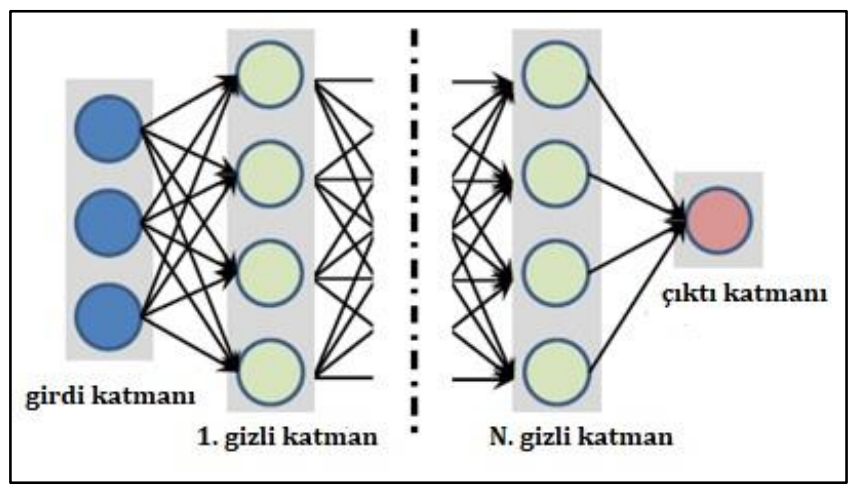

Şekil 1. Derin Sinir Ağları [3] 


\subsubsection{Derin Oto-kodlayıcılar (DOK)}

Hinton ve Salakhutdinov tarafından [4] 2006 yılında özellik çıkarımı ve boyut indirgeme için tasarlanmışlardır. Giriş ve çıkış düğümlerinin sayısı aynı olan derin oto-kodlayıcılar, giriş vektörünü yeniden oluşturma amacına dayalı denetimsiz öğrenme yöntemlerindendir (Şekil 2). Eğitim için etiketli veriye ihtiyaç duymayan derin oto-kodlayıcılar daha sağlam bir temsil elde edebilmek için birçok türde geliştirilmiştir. Geliştirilen oto-kodlayıcı yapıları şu şekildedir:

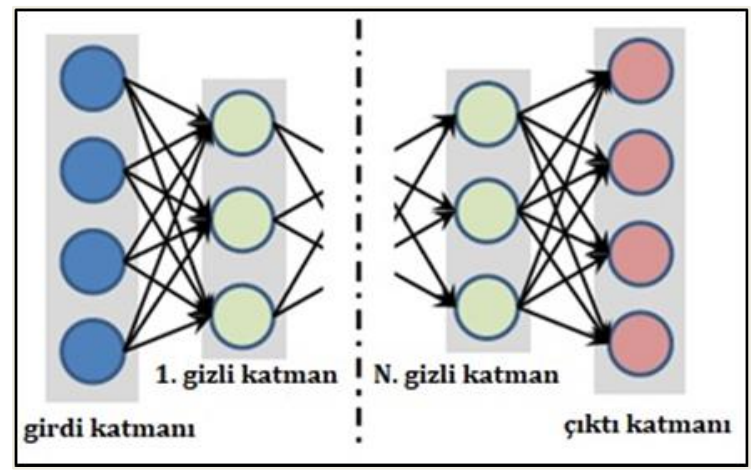

Şekil 2. Derin Oto-kodlayıcılar [3]

Seyrek (Aralıklı) Oto-kodlayıcı: Ranzato ve ark. tamamlanmamış özellikleri öğrenmek için yeni bir denetimsiz yöntem tanımlamışlardır. Evrimsel bir ağın ilk katmanını başlatmak için önerilen denetimsiz yöntemi kullanarak, MNIST veri setinde bildirilen en iyi sonuçtan biraz daha düşük bir hata oranı elde etmişlerdir [5].

Gürültü Temizleyici Oto-kodlayıcı: Vincent ve ark. açık bir kazıma kriteri ile katmanların denetimsiz olarak başlatılmasının, girdi dağılımındaki ilginç yapının yakalanmasına yardımcı olduğunu ifade etmişlerdir. Bunun da, denetimli sınıflandırma gibi daha sonraki öğrenme görevleri için daha uygun olan orta düzey temsillere yol açtığını söylemişlerdir. Oluşturdukları yapının oto-kodlayıcı eğitiminde kullanılabilirliğini ve bu gürültü temizleyici oto-kodlayıcıların derin mimarileri başlatmak için istiflenebilir olduklarını savunmuşlardır [6].

Çekme gücüne sahip Oto-kodlayıcı: Rifai ve ark. Çok Katmanlı Perseptron (ÇKP)'u başlatmak için öğrenilen özellikleri kullanarak, bir dizi veri setinde diğer sınıflandırma yöntemlerini aşarak, en gelişmiş sınıflandırma hatasını elde ettiklerini göstermişlerdir [7].

Evrişimli Oto-kodlayıcılar: Masci ve ark. önceki yaklaşımlarda bulunanlarla tutarlı olan, biyolojik olarak makul özellikleri öğrenmek için bir havuz katmanı gerektiğini savunmuşlardır. Bir ESA’nın eğitimli bir evrişimli oto-kodlayıcı yığınının filtreleriyle başlatılmasının, rakam (MNIST) ve nesne tanıma (CIFAR10) kriterlerinde üstün performans sağlayacağını iddia etmişlerdir [8].

Derin oto-kodlayıcılarda ön eğitim aşamasına ihtiyaç duyulmaktadır. Eğitim ayrıca hataların kaybolmasından dolayı zarar görebilmektedir. Bir oto-kodlayıcı sinir ağı, hedef değerleri girdilere eşit olacak şekilde ayarlayan, geri yayılma uygulayan denetimsiz bir öğrenme algoritmasıdır. Oto-kodlayıcı kimlik işlevini öğrenmeye çalışır. Oto-kodlayıcılar, yoğunluk kısıtlaması için gizli ünite sayısını sınırlandırabilirler ya da giriş piksel sayısının fazla olması için seyreklik yetenekleri ile gizli ünite sayısındaki fazlalığa izin verebilmektedirler. Böylece verilerde bulunan farklı yapıları öğrenebilmektedirler. $10 \times 10$ görüntü üzerinde bir otomatik kodlayıcı eğitimi durumu düşünüldüğünde, $n=100$ olur. Her gizli birim i, girişin bir fonksiyonunu denklem (1)'deki gibi hesaplanmaktadır:

$$
a_{i}^{(2)}=\mathrm{f}\left(\sum_{j=1}^{100} W_{i j}^{(1)} x_{j}+b_{i}^{(1)}\right)
$$

\subsubsection{Derin İnanç Ağları (DİA)}

Hinton ve ark. [9] tarafından önerilen derin inanç ağları her bir alt ağın gizli katmanının bir sonraki için görünür katman işlevi gördüğü Kısıtlı Boltzmann Makinesi'nin (KBM) bileşimidir (Şekil 3). En üstteki ilk iki katmanda sadece yönsüz bağlantılar bulunmaktadır. Bu yapı ağın hem denetimli hem de denetimsiz olarak eğitilmesine izin vermektedir. Ağın başlatılması için katman açgözlü öğrenme stratejisi önerilmektedir. En yüksek olasılıklı olan bilgilerin çıkarımı yapılmaktadır. Başlangıç prosedürü ve örnekleme nedeniyle eğitim aşaması hesaplama açısından pahalıdır. 


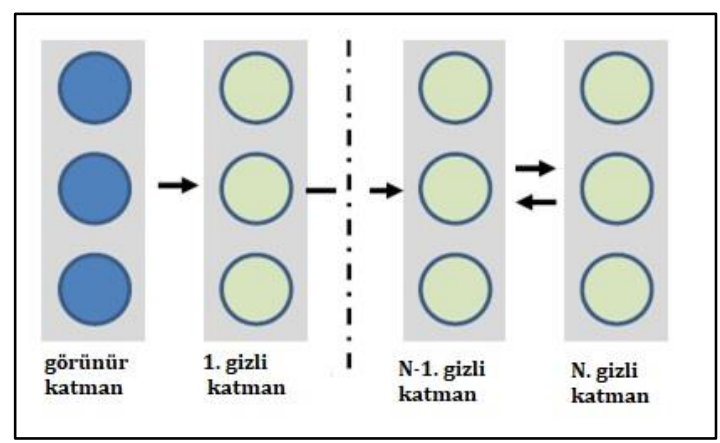

Şekil 3. Derin İnanç Ağları [3]

\subsubsection{Derin Boltzmann Makinesi (DBM)}

Salakhutdinov ve Hinton tarafından önerilen derin Boltzmann makinesi, Boltzmann ailesine ait başka bir derin öğrenme yaklaşımıdır [10]. Ağın tüm katmanları arasında yönsüz bağlantılara (koşullu bağımsız) sahip bir yöntemdir (Şekil 4). Olasılık alt sınırının en yüksek değerini elde edebilmek için 1999 yılında Younes tarafından önerilen stokastik maksimum olasılık algoritmasını [11] kullanmaktadır. Ağ yapısı belirsiz girdiler ile daha sağlam bir sonuç elde etmek için yukarıdan aşağıya doğru geri bildirim sağlamaktadır. Parametrelerin en iyilemesi büyük veri setlerinde kullanışlı değildir.

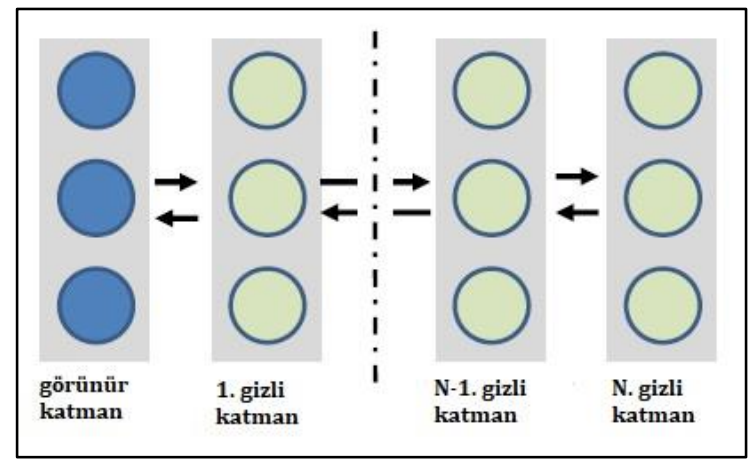

Şekil 4. Derin Boltzmann Makinesi [3]

\subsubsection{Yinelemeli Sinir Ağları (YİSA)}

1989 yılında Williams ve Zipser tarafından önerilen yinelemeli sinir ağları [12] veri akışını analiz edebilen bir sinir ağı yapısına sahiptir (Şekil 5). Bu ağlar çıktının önceki hesaplamalara bağlı olduğu uygulamalar için daha kullanışlıdır. Tüm adımlarda aynı ağırlıkları paylaşan yinelemeli derin sinir Ağları, sıralı olan olayları ezberleyebilmekte ve zaman bağımlılığını modelleyebilme özelliğine sahiptir. Doğal dil işleme uygulamalarında sıklıkla kullanılan bu yöntem bu alanda birçok uygulamada başarılı olmuştur. Eğimin sıfır olması ve ani yükselmesi gibi problemler nedeniyle öğrenmede sorunlar yaşanmaktadır.

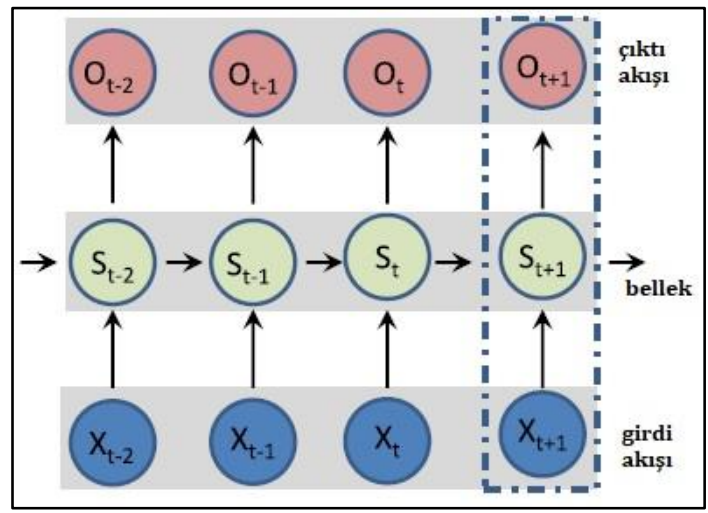

Şekil 5. Yinelemeli Sinir Ağları [3]

\subsubsection{Evrişimli Sinir Ağları (ESA)}

LeCun ve ark. tarafından 1998 yılında önerilen evrişimli sinir ağları [13] görüntü gibi 2 boyutlu veriler için daha uygundur. Her bir gizli evrişim filtresi, girdisi nöron aktivasyonlarının 3 boyutlu bir çıktısına dönüş̧ürmektedir (Şekil 6). Evrişimli sinir ağları oluşturulurken 1962 yılında Hubel ve Wiesel tarafından ortaya konan [14] görsel korteksin nörobiyolojik modelinden esinlenilerek geliştirilmiştir. Tipik bir sinir ağına göre daha az sayıda nöron bağlantısına ihtiyaç duymaktadır. Evrişimli sinir ağları için birçok farklı model söz konusudur. Krizhevsky ve ark. tarafından görüntü sınıflandırılması için oluşturulan AlexNet [15], Szegedy ve ark. tarafından önerilen [16] Google Net örnek olarak verilebilir. Evrişimli Sinir Ağları görsel niteliklerin arasındaki tüm hiyerarşik yapıyı 
bulmak için birden fazla katmana ihtiyaç duyabilmektedir. Genellikle etiketli görüntülerin büyük bir veri kümesine ihtiyaç duymaktadır.

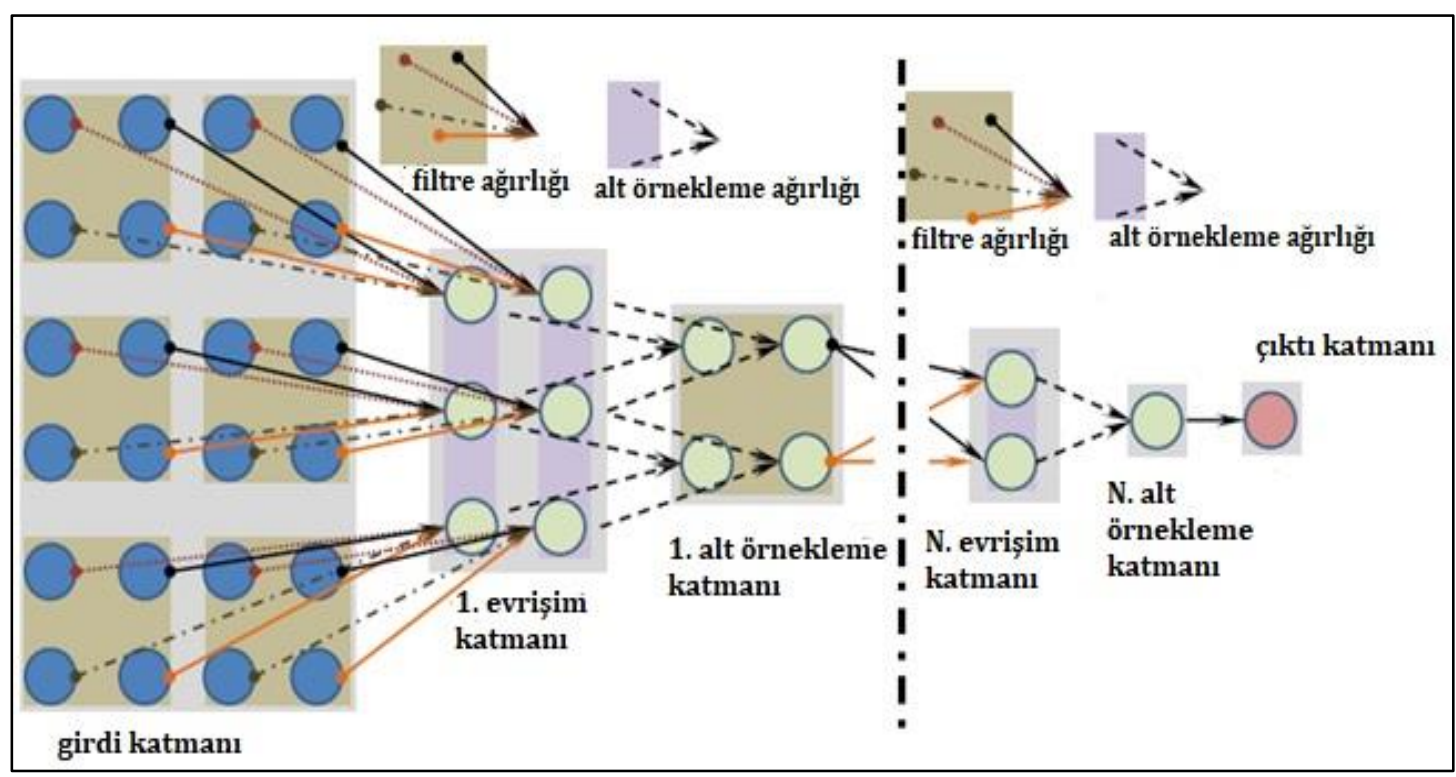

Şekil 6. Evrişimli Sinir Ağları (ESA) [3]

\subsection{Derin Öğrenme Yöntemlerinin Uygulanma Alanları}

Derin öğrenme ile ilgili yapılan çalışmalardan eğitim süresinin uzun olması nedeniyle 2006 yılına kadar verim alınamamıştır [17]. 2006 yılında Hinton ve arkadaşlarının DİA'ların eğitimi için önerdikleri hızlı öğrenme algoritması [18] ile derin öğrenmedeki gelişmeler hız kazanmıștır. Bununla birlikte Bengio ve arkadaşlarının derin sinir ağlarının açgözlü katmanlarla eğitimi [19] ile ilgili yaptıkları çalışma ve Ranzato ve arkadaşlarının enerji modelini temel alarak etkin seyrek temsili öğrenme üzerine [5] yaptıkları çalışmalarda derin öğrenme alanında devrim niteliğindedir.

Yapılan bu çalışmalarda temsili zor olan denetimsiz öğrenme ile katmanların eğitimi gerçekleştirilmektedir. Bununla birlikte önceden eğitilmiş olan katmanlar tekrar denetimsiz öğrenme ile de eğitilmektedir. Seviyeler boyunca gerçekleştirilen öğrenmenin sonucu olan gösterim bir sonraki katmanın girdisini oluşturmaktadır. Katmanların ince ayarı içinde denetimli öğrenme modeli kullanılmıştır. Her bir katmanda denetimsiz öğrenme için [19] KBM'lerin kullanılması ile Bengio ve arkadaşları oto-kodlayıcılar ile KBM' leri karşılaştırmışlardır. Ranzato ve arkadaşları [5] evrişimsel mimaride seyrek oto-kodlayıcılar kullanmışlardır.

Derin oto-kodlayıcılar üzerine Hinton ve arkadaşlarının yaptığı çalışmada ise [20] veri boyutunu azaltarak açgözlü katmanlara sahip öğrenme modeli kullanmışlardır. Salakhutdinov ve Hinton sınıf komşuluğu yapısını koruyarak doğrusal olmayan gömülü öğrenme [21] ile de açgözlü katman kullanarak öğrenme yöntemini k-en yakın komşuluk (k-nn) sınıflamasına uygulamışlardır.

Le Roux ve Bengio KBM'lerin üstel genişleme özelliği evrensel yaklaşımını kullanarak KBM'lerin ve DİA'ların temsil gücünü ortaya koymuşlardır [22]. Yaptıkları çalışmada Hinton ve arkadaşları tarafından önerilen açgözlü katmana sahip derin öğrenme yaklaşımına KBM'lerin derin modellerin eğitimindeki başarısını öne sürerek önerdikleri modele gizli birimler eklemişlerdir. Bu şekilde daha fazla katmana sahip DİA'ların eğitiminde KBM’lerin kullanılmasıyla yeni bir yöntem ve daha az açgözlü bir öğrenme modeli önermişlerdir.

Sutskever ve Hinton, [23] üssel yaklaşımlı derin inanç ağlarının katman genişliklerinin veri boyutu ile sınırlı da olsa ikili vektörler üzerindeki dağılımları gelişigüzel doğruluk değerlerine yakınlaştırabildiklerini göstermişlerdir. Bununla birlikte bu ağların daha kolay ve daha pratik bir şekilde açgözlü öğrenme yaklaşımına olan uygunluklarını ispatlamışlardır.

Ranzato ve arkadaşları ise [24] nesne tanıma uygulamaları için küçük değişiklik ve bozulmalardan etkilenmeyen seyrek özellik detektörleri için sabit özellikli hiyerarşik yapıya sahip denetimsiz öğrenme modeli önermişlerdir. Elde ettikleri özellik çıkarıcının birden fazla evrişim filtresinin uygulanmasından sonra ardışık pencerelerdeki her bir filtrenin çıktııın maksimum değerini hesaplayan bir özellik havuzu oluşturucu katman ve doğrusal olmayan bir sigmoid fonksiyonu içerdiğini ifade etmişlerdir. İkinci aşamada, daha değişken ve daha büyük özellikler ilk seviye özelliklerin yamalarında aynı algoritma ile eğitilerek elde edilmektedir. Denetimli sınıflandırıcının bu özellikler ile eğitilmesi, MNIST veri tabanında \% 0,64 hata ve her bir kategoride eğitilmiş 30 örnek ile Caltech 101 veri kümesinde \% 54 ortalama bir tanıma oranı sağlamıştır. Ortaya çıkan mimarinin evrişimsel ağlarla benzerlikleri olduğunu, katmanlı denetimsiz öğrenme sürecinin denetimli öğrenme süreçlerinde yaşanılan parametre sorunlarının azaltılmasında ve çok az etiketli eğitim verisiyle iyi bir performans gösterdiğini ifade etmişlerdir. Tablo 1'de derin öğrenme yöntemleri ve kullanıldıkları alanlar görülmektedir. 
Tablo 1. Derin ögrenme yöntemleri ve kullanım alanlart

\begin{tabular}{l|l}
\hline Derin Öğrenme Yöntemleri & Derin Öğrenme Yöntemlerinin Kullanıldığı Alanlar \\
\hline Boltzmann makinesi & Sınıflandırma ve en iyileme \\
\hline Derin inanç ă̆larl & Sinıflandırma, robotik ve bilgisayar görüsü \\
\hline Derin ileri beslemeli ağlar & Regresyon, sınıflandırma, tahmin, robotik ve bilgisayar görüsü \\
\hline Evrişimli sinir ăgları & Regresyon, sınıflandırma, robotik ve bilgisayar görüsü \\
\hline Yinelemeli sinir ăgları & Regresyon, sınıflandırma, tahmin, robotik ve bilgisayar görüsü \\
\hline
\end{tabular}

Derin öğrenmenin birçok alanda uygulamaları vardır. Görüntü ve ses senkronizasyonu [25], fotoğraf çözünürlüğünü arttırma [26], gerçek zamanlı kişi konum analizi [27], fotoğraf açıklama [28], fotoğraftaki insanların bakışlarında değişiklik yapma [29], gerçek zamanlı davranış analizi [30], fotoğraflardan yeni fotoğraf oluşturma [31], galaksi ve yanardağ resimleri oluşturma[32, 33] görüntü alanındaki derin öğrenme çalışmalarına örnek verilebilmektedir. Bununla birlikte farklı diller arasında çeviride de derin öğrenme kullanılmaktadır [34]. Biyoloji alanında ise balina ve plankton sınıflandırması için de derin öğrenme kullanılmaktadır [35-38]. Yeni görüntüler oluşturma [39], fotoğraf ve videolardan metin okuma [40] gibi alanlarda da derin öğrenme kullanılmaktadır. Bilgisayar oyunları[41], otonom araçlar[42] ve robotik [43,44] de derin öğrenmenin kullanıldığı alanlardır. Nesne tanıma [45], demografik yapının tahmini [46] ve seçim sonuçlarının tahmini [47] alanlarında da derin öğrenme uygulanmaktadır.

\subsubsection{Sağlık Alanında Kullanılan Derin Öğrenme Yöntemlerinin Kullanım Alanları}

Bu bölümde sağlık alanında kullanılan derin öğrenme yöntemlerinin kullanım alanları açıklanarak, bu alanlarda yapılan çalışmalar incelenmiştir.

\subsubsection{Biyoinformatik Alanında Kullanılan Derin Öğrenme Yöntemleri}

Derin öğrenme yöntemleri, kanser teşhisi, gen seçimi ve sınıflandırması, gen çeşitliliği, ilaç tasarımı, bileşim protein etkileşimi, RNA ile protein ilişkisi ve DNA metilasyonu gibi biyoinformatik uygulamalarında kullanılmaktadır. Tablo 2‘de biyoinformatik uygulamalarında kullanılan derin öğrenme yöntemleri ve hangi alanda kullanıldıkları gösterilmiştir.

Tablo 2. Biyoinformatik alanında kullanılan derin öğrenme yöntemleri

\begin{tabular}{l|l}
\hline Biyoinformatik Uygulamaları & Uygulanan Derin Öğrenme Metotları \\
\hline Kanser teşhisi & $\begin{array}{l}\text { Derin oto-kodlayıcılar } \\
\text { Derin inanç ağları } \\
\text { Derin sinir ağları }\end{array}$ \\
Gen çeşitliliği & Derin sinir ağları \\
\hline İlaç tasarımı & Derin sinir ă̆ları \\
\hline Bileşim-protein etkileşimi & Derin inanç ağları \\
RNA ile protein İlişkisi & \\
DNA metilasyonu & \\
\hline
\end{tabular}

Sağlık alanında 2013 yılında Fakoor ve ark. nın gen çıkarımı verilerini kullanarak farklı kanser türlerini belirlemek, kanser tanısını ve sınıflandırmasını geliştirmek için derin öğrenme yöntemlerinden DOK yöntemini kullandıkları bilinmektedir. Yaptıkları çalışmada danışmansız özellik öğrenimi yöntemini kullanarak özellik çıkarımı için boyut azaltımı temelli bir yaklaşım belirlemişlerdir [48].

Ibrahim ve ark. [49] elde ettiği deneysel sonuçlar, yaklaşımın hepatoselüler karsinoma (HCC) klasik özellik seçim yöntemlerini $\%$ 9, akciğer kanseri \% 6 ve meme kanserinde F1 ölçümünde \% 10'dan daha iyi bir performans gösterdiğini söylemişlerdir.

Khademi ve ark. nın göğüs kanserinin genetik teşhisi için yaptıkları çalışmada, mikro dizilimli verilerden özellik çıkarmak ve eksik özellikleri uyarlamak ve gürültüyü gidermek için DİA ile olasılıksal grafiksel modellerden olan Bayes ağlarını birleştirmişlerdir [50]. Tıp uygulamalarında tahmin modelleri oluşturmak için uygun olan meme kanseri prognozu ve tanısı için olasılıksal bir grafik modeli (PGM) önermişlerdir. Kanserin temelde genetik bir hastalık olduğunu, mikro dizi ve klinik verilerin entegrasyonu, bir öngörü modelinin doğruluğunu artırabileceğini ifade etmişlerdir. Bununla birlikte, mikro dizi verileri yüksek boyutlu olduğundan, genomik değişkenler de dâhil olmak üzere, boyut ve küçük örneklem büyüklügüu problemlerinden dolayı yapı ve parametre öğrenmede zayıf sonuçlara neden olabileceğini belirtmişlerdir. Bu problemi, manifold öğrenme ve mikro dizi verisine DİA uygulayarak ele almışlardır. Klinik verilere yapı öğrenme algoritması uygulayarak klinik modelin yapısını otomatik olarak çıkartmışlar ve daha sonra, bu iki modeli softmax düğümlerini kullanarak entegre etmişlerdir. METABRIC ve NKI gibi gerçek dünya veri tabanlarını kullanan kapsamlı deneyler, tümörleri sınıflandırmak ve rekürrens ve metastaz gibi olayları tahmin etmek için destek vektör makineleri (SVM'ler) ve ken yakın komşuluk (k-nn) sınıflandırıcılarına kıyasla umut verici sonuçlar verdiğini ifade etmişlerdir.

Quang ve ark. [51] genetik varyantların patojenitesini açıklamak için derin öğrenme yaklaşımı kullandıkları çalışmalarında lojistik regresyon, destekli vektör makinesi ve derin sinir ağlarından oluşan 3 farklı modeli karşılaştırmışlardır. Sonuçta S VM, LR ve DSA modellerinin sınıflandırma doğrulukları sırasıyla \% 58, 2, \% 59, 8 ve \% 66, 1'dir. Buna rağmen DSA 'nın doğruluğunun lineer olarak yetersiz olduğunu iddia etmişlerdir. İddialarına dayanak olarak da eğitim verilerinin yanlış etiketlenmiş numuneler ile 
şişirilebileceğini ve genomdan rastgele olarak örneklendirilen varyantların işlevsel olmayabileceğidir. Fonksiyonel tahmin için genom analizinde kullanılan örneklerin yetersiz olduğunu ve modelin eğitim için iyileştirmeye ihtiyaç duyulduğunu savunmuşlardır.

Ramsundar ve ark. [52] DSA'ların ilaç keşfi için bir öğrenme çerçevesi sağladıklarını belirtmişlerdir. Çalışmalarında farklı birçok kaynaktan elde edilen biyolojik verileri çok görevli sinir ağı mimarileri ile sentezleyerek ilaç tasarımı yapmaya çalışmışlardır. $\mathrm{Bu}$ mimarileri eğitmek için, 200'den fazla biyolojik hedefe yönelik yaklaşık 40 milyon ölçümden oluşan bir veri kümesi oluşturmuşlardır. Elde ettikleri sonuçlara göre; Kitlesel çoklu görev ağlarının, tek görevli yöntemlerden önemli ölçüde daha iyi bir tahminsel doğruluk değerine sahip olduğunu, çoklu görev ağlarının öngörü gücünün, ek görevler ve veriler eklendikçe arttığını belirtmişlerdir. Toplam veri miktarı ve toplam görev sayısının, çoklu görev geliştirmeye önemli ölçüde katkıda bulunduğunu söylemişlerdir. Çoklu görev ağlarının görevlere sınırlı aktarım sağladıklarını ifade etmişlerdir.

Zhang ve ark. derin ESA kullanarak bebek beyin görüntülerini gruplandırmaya çalışıı̧lardır. Önerdikleri modelin bebeklerin beyin dokusunun segmentasyonunda daha önce kullanılan yöntemlerden daha iyi sonuçlar verdiğini göstermişlerdir[53].

Tian ve ark. [54] bileşik protein etkileşimlerini (CPI) tahmin için DSA kullanmışlardır. Derin öğrenmeye dayalı CPI tahmini için DL-CPI olarak adlandırılan bir yöntem önermişlerdir. Küçük bir veri kümesi üzerinde eğitilen DSA modeli ile hiperparametreleri elde etmişlerdir. Bu hiperparametreler bileşik protein tahmini ve DSA modelinin daha büyük veri setlerindeki eğitimleri için önem taşımaktadır. Çoklu performansı dikkate alarak kullanılmakta olan tahmin yöntemleri ile önerdikleri DL-CPI yöntemini karşılaştırdıklarında, DL-CPI yönteminin genellikle diğer yöntemlerden daha iyi sonuçlar verdiğini ifade etmişlerdir.

Angermueller ve ark. [55] tek hücreli DNA metilasyonunun doğru tahmini için derin öğrenmeye dayalı bir yöntem önermişlerdir. Önerdikleri yöntemi, tek hücre DNA metilasyon verileri üzerinde, alternatif sıralama protokolleri kullanılarak oluşturulan beş farklı hücre tipinde değerlendirmişlerdir. Bu yöntem, önceki yöntemlerden önemli ölçüde daha doğru tahminler vermiştir.

\subsubsection{Medikal Görüntülemede Kullanılan Derin Öğrenme Yöntemleri}

3 Boyutlu beyin rekonstrüksiyonu, nöral hücre sınıflandırması, beyin doku sınıflandırması, Alzheimer teşhisi, doku sınıflandırması, organ bölütlemesi, hücre kümeleme, iç kanama tespiti ve tümör tespiti derin öğrenme yöntemlerinin kullanıldığı medikal görüntüleme uygulamalarıdır. Tablo 3 'te medikal görüntüleme alanında kullanılan derin öğrenme yöntemleri ve hangi alanlarda kullanıldıkları gösterilmiştir.

Tablo 3. Medikal görüntülemede kullanılan derin öğrenme yöntemleri

\begin{tabular}{|c|c|}
\hline Medikal Görüntüleme Uygulamaları & Uygulanan Derin Öğrenme Metotları \\
\hline $\begin{array}{l}\text { Doku sınıflandırması } \\
\text { Organ bölümlemesi } \\
\text { Hücre kümeleme } \\
\text { İç kanama tespiti } \\
\text { Tümör tespiti }\end{array}$ & $\begin{array}{l}\text { Evrişimli derin inanç ağları } \\
\text { Evrişimli sinir ağlarl } \\
\text { Derin oto-kodlayıcılar } \\
\text { Derin sinir ağlarl }\end{array}$ \\
\hline
\end{tabular}

Shan ve Li [56] göz içinin arka bölümünün (fundus) görüntülerindeki mikro anevrizmanın otomatik olarak tespiti için iki katmanlı yığılmış seyrek otomatik kodlayıcı modeli önermişlerdir. Önerdikleri modelde, piksel seviyesinden itibaren yüksek seviyedeki özellikleri elde edebilmek için denetimsiz öğrenme yöntemini kullanmışlardır. Bir modelde ikili sınıflandırma Lojistik regresyon ile gerçekleştirilebilmektedir. Ancak modelin daha fazla sınıf etiketine ihtiyaç duyduğu durumlarda Lojistik regresyonun, genelleştirilmiş hali olan softmax algoritması denetimli öğrenme yöntemlerinde kullanıldığı gibi, derin öğrenme yöntemleri ile birlikte denetimsiz özelliklerin öğrenilmesinde de kullanılabilmektedir.

Softmax yöntemi ikiden fazla sonucun oluştuğu rakam tanıma probleminde rakamları ayırt etmede başarılıdır. Softmax sınıflandırıcısı yüksek seviyeli özelikleri kullanarak fundustaki bozukluk veya hasarları görüntülerden tespit edebilmektedir. Herhangi bir ön işlem yapılmadan doğrudan ham görüntü parçalarının öğrenilmesinde önerdikleri model başarılı olmuştur. Bununla birlikte, kullanılan softmax sınıflandırıcısı yamalar arasındaki ayırt edici özelliklerin otomatik olarak çıkarılmasında iyi bir performans göstermiştir. İnce ayarın sınıflandırma performansına olumlu bir katkı yaptığını belirtmişlerdir. 10 kat çapraz doğrulama kullanarak test ettikleri modellerinde ince ayar işleminin kullanılması sonucunda ROC eğrisi altında ortalama (AUC) \% 96,2’ lik bir alan elde etmişlerdir. Manyetik Rezonans Görüntüleme (MRG) vücut içerisindeki organ ve dokulara ait ayrıntılı görüntüler ortaya çıkarmak için manyetik alan içerisinde radyo frekansları kullanılarak uygulanan bir tanı yöntemi olarak ifade edilmektedir. Tüp şeklinde geniş mıknatıslara sahip olan MRG cihazından yayılan radyo dalgaları tarafından oluşturulan kesitler bu cihazın ekranında birikmektedir. Kesitlerin birikmesi ile oluşan görüntüler farklı açılardan incelenebilecek 3 boyutlu görsellere dönüştürülebilmektedir. Mansoor ve ark. [57] MRG dizisi ve derin öğrenme tarafından yönlendirilen AVP (Ön görsel yol segmentasyonu) için tam otomatik bir bölünmüş şekil modeli önermişlerdir. AVP segmentasyonunda şekil modelini yönlendirmek için MRG dizilerinden öğrenen bir derin öğrenme yöntemi olarak yığılmış otomatik kodlayıcı (SAE) tabanlı bir derin öğrenme modeli önermişlerdir. Önerdikleri model, 165 pediatrik denekten elde edilen MRG dizileri üzerinde değerlendirilmiştir. AVP 'nin tamamının segmentasyonu için bir kez dışarıda bırakma doğrulaması kullanmışlar ve ortalama 0.779 zar benzerlik katsayısı elde etmişlerdir. Sonuçlar, önerilen yerelleştirilmişş şeklin ve 
seyrek görünüme dayalı öğrenme yaklaşımının mevcut son teknoloji yaklaşımlarını önemli ölçüde geride bıraktığını ve manuel kadar sağlam olduğunu göstermiştir.

Nie ve ark. glioma adı verilen beyin tümörünün erken teşhisi için yaptıkları çalışmada yüksek dereceli glioma hastalarının ameliyat öncesindeki çok modlu beyin görüntülerinden otomatik özellik çıkarımı yapabilmek için derin öğrenme yöntemini kullanmışlardır. Özellikle, 3 boyutlu ESA'yı benimsemiş ve çok kanallı veri ve danışmanlı özellik öğrenme ile yeni bir ağ mimarisi önermişlerdir. Klinik özelliklere odaklı, hastanın sağ kalım süresini öngörmek için destekli vektör makinesinde eğitim yapılmıştır. Kullandıkları yöntem \% 89,9 doğruluk değeri elde etmiştir. Çok modlu beyin görüntülerinden öğrenilen özelliklerin doğru zaman tahmininde önemli bir rolü olduğunu ortaya koymuşlardır [58].

Kleesiek ve ark.[59] derin MRG görüntülerinden beyin çıkarımı yapmaya çalışmışlardır. Kafatası sıyırma için 3 boyutlu ESA kullanmışlardır. İkili maskeleri üretmek için kesme eşiğinin ESA’nın olasılık çıktısından üretilmesinin, yöntemin hassasiyetini arttırmak için kullanılabileceğini ifade etmişlerdir. Ancak bunun özgüllüğün azalmasına sebep olabileceğini ve uygulamaya özel olarak karar verilmesi gerektiğini vurgulamışlardır. Optimize edilmiş bir GPU uygulaması kullanarak tahminlerin bir dakikadan daha kısa sürede gerçekleştirilebileceğini ve önerilen yöntemin, büyük ölçekli çalışmalar ve klinik denemeler için faydalı olabileceğini söylemişlerdir.

Jiang ve ark. görüntülerde ön işleme yapabilen ve somatik hücre kaynağındaki sinir öncü ve sinir öncü olmayan hücreleri sınıflandırabilen ESA temelli yeni bir tanıma sistemi önermişlerdir. Puleripotent kök hücreleri, sınırsız çoğalma yeteneğine sahip, embriyonik kök hücre olarak da bilinen bütün organ ve dokulara dönüşebilen rejeneratif tıp için önemli olan, gelişen embriyoda ektoderm hücreleri tarafından oluşturulan iç hücre kitlesidir. Elde ettikleri deneysel sonuçlar ile önerdikleri sistemin uyarılmış puleripotent kök hücreleri ve sinir öncü hücrelerinden ilaç üretilmesi ile ilgili araştırmalarda kullanılabilecek yeni bir araç sağladığını kanıtlamışlardır [60].

Havaei ve ark. MRG görüntülerinden fokal beyin patolojisi segmentasyonu için GPU destekli ESA uygulamasını medikal görüntülemede kullanmışlardır [61]. Yöntemleri başarılı sonuçlar elde etmiş̧ir. Oluşturulan ESA modelinde İlk satırda, iki yollu ESA bulunmaktadır. Girdi yaması, her biri yerel bir ağdan oluşan iki ağ ve global bir yol üzerinden geçmektedir. Yerel ve küresel yollardaki özellik haritaları sarı ve turuncu renkte gösterilmektedir. İkinci satırda art arda girdili ESA bulunmaktadır. Sınıf olasılıkları iki yollu ESA tarafından üretilen ikinci bir ESA modelinin girdisi ile birleştirilmektedir. Üçüncü satırda, kademeli girdili ESA kullanılarak tam görüntü tahmini yapılmaktadır.

Suk ve ark. [62] Derin öğrenme yoluyla nöro görüntüleme yöntemlerinden üst düzey gizli ve paylaşılan özellik gösterimi için yeni bir yöntem önermişlerdir. Özellikle, 3 boyutlu bir yamayla gizlenmiş hiyerarşik özellik gösterimini bulmak için bir yapı bloğu olarak KBM'ye sahip derin bir ağ olan Derin Boltzmann Makinesini (DBM) kullanmışlardır. Çok modelli bir DBM ile eşleştirilmiş MRG ve PET (Pozitron emisyon tomografisi) yamalarından ortak özellik gösterimi için sistematik bir yöntem geliştirmişlerdir. Önerilen yöntemin etkinliğini doğrulamak için, ADNI (Alzheimer Hastalığı Nöro Görüntüleme Girişimi) veri kümesi üzerinde deneyler yapmışlar ve elde ettikleri sonuçları son teknoloji yöntemlerle karş̧laştırmışlardır. AD (Alzheimer hastası) ve sağlıklı (Normal Kontrol) NC, MCI (Hafif bilişsel bozukluk) ve NC, MCI dönüştürücü ile MCI dönüştürücü olmayan üç ikili sınıflandırma problem üzerinde çalışmışlardır. Eğitimli modelin görsel incelemede diğer yöntemlerden daha iyi performans gösterdiğini ve sırasıyla\% 95,35, \% 85,67 ve \% 74,58 oranlarında maksimum doğruluk değerini elde ettiğini ifade etmişlerdir.

Kuang ve He [63] dikkat eksikliği hiperaktivite bozukluğunu (ADHD) araştırmışlardır. Kamuya açık veri setinde ADHD verilerinin özelliklerine göre yapıyı ve parametreleri ayırt etmek için derin öğrenme modellerinden biri olan DSA 'i özellik ve sınıflandırma için kullanmıştır. Denekleri kontrol, kombine, dikkatsiz veya hiperaktif gibi frekans özelliklerine göre tahmin etmişlerdir. Sonuçlar, diğer yöntemler ile karşılaştırıldığında büyük ölçüde iyileşme sağlamıştır. Uyguladıkları derin öğrenme yönteminin ADHD 'nin (Fonksiyonel manyetik rezonans görüntüleme) fMRG verileri ile ayırt edilmesinde ilk kez kullanıldığını iddia etmişlerdir.

Li ve ark. Alzheimer hastaları ile hafif bilişsel bozukluk hastalarının teşhisi için yaptıkları çalışmada dayanıklı ya da sağlam olarak ifade edilen Derin Öğrenme yöntemini geliştirmişlerdir. Uyguladıkları yöntem diğer derin öğrenme metotlarına göre \% 5.9 oranında doğruluk sınıflandırmasında daha iyi sonuç vermiştir [64].

Fritscher ve ark. [65] çalışmalarında, 3 boyutlu tıbbi görüntülerin hızlı segmentasyonu için ESA kullanmışlardır. ESA modelinde girdi olarak görüntü yamalarının kullanmalarının yanı sıra, şekil ve konum bilgisini ESA eğitimi için yoğunluk bilgisi ile birleştiren ortogonal yamalar da kullanmışlardır. Bu amaçla, baş-boyun bölgesi için BT (Bilgisayarlı Tomografi) veri kümesi kullanılmış ve sonuçları diğer atlas ve model tabanlı yaklaşımlar ile karşılaştırmışlardır. Sunulan yaklaşımın tamamen otomatik ve hızlı olduğunu, bununla birlikte belirli anatomik yapılarla sınırlı olmadığını öne sürmüşlerdir. Yaptıkları nicel değerlendirmenin iyi sonuçlar verdiğini ve tıbbi görüntülerin bölümlendirilmesinde derin öğrenme yaklaşımları için büyük potansiyel olduğunu söylemişlerdir.

Zhen ve ark. [66] çift ventrikül hacim tahmini için DİA mimarisini kullanmışlardır. Büyük ölçekli derin ağlar tarafindan denetimsiz kardiyak görüntü temsili öğrenme ve rastgele ormanlar tarafindan doğrudan çift ventrikül hacim tahmini olarak iki ana tam öğrenme aşamasından oluşan genel bir regresyon çerçevesi tanımlamışlardır. Üretken ve ayırt edici öğrenmenin güçlü yanlarından faydalanan önerdikleri yöntemin, daha önceki yöntemlerde kullanılan hastaların iki katı olan hem sağlıklı hem de hastalıklı vakaları içeren 100 denekten oluşan daha geniş bir veri setinde, uzmanlar tarafindan hem sol hem de sağ ventrikül için toprak dişına çıkma çapraz onaylama yöntemiyle karşılaştırıldığında yaklaşık 0,92 'lik yüksek korelasyonlar ürettiğini ve büyük ölçüde mevcut doğrudan yöntemlerden daha iyi performans gösterdiğini söylemişlerdir. Bununla birlikte önerdikleri yöntemin, klinik kardiyak fonksiyon analizinde pratik olarak kullanımının yanında, diğer organ hacmi kestirim görevlerine kolayca genişletilebileceğini iddia etmişlerdir. 


\section{Avrupa Bilim ve Teknoloji Dergisi}

Brotsch ve Tam [67] mevcut beyin manifoldu öğrenme yöntemlerinden farklı olarak, manifold alanının yerel olarak doğrusal olmasını gerektirmeyen ve önceden tanımlanmış bir benzerlik ölçüsü veya önceden oluşturulmuş bir yakınlık grafiği gerektirmeyen 3 boyutlu beyin görüntülerinin manifoldunu öğrenmek için bir öğrenme modeli geliştirmişlerdir. Bu modelde, nesne tanıma görevlerindeki başarılarından dolayı son zamanlarda bilgisayarlı görme alanında çok dikkat çeken derin öğrenmeye, katmanlı ağları DİA kullanan bir makine öğrenme yaklaşımı önermişlerdir. DİA'ların geleneksel olarak çok sayıda eğitilebilir parametre nedeniyle 3 boyutlu görüntülere uygulanmasının aşırı derecede pahalı olduklarını söylemişlerdir. $128 \times 128 \times 128$ çözünürlükteki 3 boyutlu tıbbi görüntülerin DİA'ler için hesaplama açısından daha verimli bir eğitim yöntemi olduğunu göstermişler ve DİA'ların, demografik ve hastalık parametrelerine bağlı olan çeşitlilik modlarını tespit eden düşük boyutlu beyin hacimleri manifoldunu öğrenebildiğini ifade etmişlerdir.

Xu ve ark. servikal displazi tanısı için çok modlu derin öğrenme yöntemi tasarlamışlardır. Düşük seviyeli görüntü verilerini diğer görüntüsüz modeller ile birleştirilebilen bir özellik vektörüne dönüştürmek için ESA kullanmışlardır. Önerdikleri çok modelli yap1, görüntülü ve görüntüsüz yöntemlerden daha iyi tamamlayıcı özellikleri öğrenebilen baştan sona bir derin ağdır. Servikal displazi tanısı için, geniş bir veri kümesinde \% 90 özgüllük, \% 87,83 duyarlılıkta, tek bir bilgi kaynağını kullanan ve daha önceki çok modlu yapılardan daha iyi bir performans gösterdiği sonucuna ulaşmışlardır [68].

Avendi ve ark. [69] kısa eksenli kardiyak MRG veri setlerinden tam otomatik bir SV (Sol Ventrikül) segmentasyonu aracı geliştirmek ve değerlendirmek için deforme edilebilir modeller ile birlikte derin öğrenme algoritmalarına başvurmuşlardır. Önerdikleri yöntemde MRG veri setindeki SV odasını otomatik olarak tespit etmek için derin evrişimli ağları, SAE`leri de SV şeklini çıkarmak için kullanmışlardır. Çıkarılan şekli, segmentasyonunun doğruluğunu ve sağlamlığını geliştirmek için deforme edilebilir modellere dâhil etmişlerdir. Toronto, Kanada'daki Sunnybrook Sağlık Bilimleri Merkezi'nden elde edilen MICCAI çevrimiçi olarak kamuya açık olan veri tabanından MICCAI 2009 verilerini kullandıkları SV segmentasyonunun zorluğundan 45 kardiyak MRG veri seti ile yöntemlerini doğrulamışlardır. Kullandıkları yöntemin diğer yöntemlerden daha iyi performans gösterdiğini ve temel gerçeğe mükemmel uyum sağladığını söylemişlerdir. Doğrulama metrikleri, iyi kontur yüzdesi, zar metrik, ortalama dik mesafe ve uygunluk yüzdesi olmak üzere, $\% 96,69,0,94,1,81 \mathrm{~mm}$ ve 0,86 olarak hesaplamışlardır. 79,2-95,\% 62, 0,87-0,9, 1,76-2,97 mm ve 0,670,78 'e göre, sırasıyla diğer yöntemlerle elde edilmiştir.

Yu ve ark. [70] çalışmalarında, doktorların inceleme zamanından tasarruf etmeyi amaçlayan kablosuz kapsül endoskopisi (WCE) görüntüleri için sindirim organlarının sınıflandırma problemini incelemişlerdir. Extreme Learning Machine (ELM) içeren Hibrid bir ESA tarafından WCE sınıflandırma sistemi tasarlamışlardır. Yaklaşımlarında, ESA'i veri odaklı bir özellik çıkarıcısı olarak seçmişler ve basamaklandırılmış ELM 'yi derin ESA sınıflandırma sisteminde geleneksel olarak kullanılan tam bağlantılı sınıflandırıcı yerine güçlü bir sınıflandırıcı olarak yapılandırmışlardır. Ayrıca, ELM 'nin yakınsama ve sınıflandırma kapasitesini denetlemek için yeni bir başlatma kullanmışlardır. Geliştirilmiş WCE görüntü sınıflandırma sistemlerini HESA-NELM olarak adlandırmışlardır. Yaklaşık 1 milyon gerçek WCE imgesiyle yöntemin performansını değerlendirmek için yoğun deneyler yapmışlardır. Önerdikleri yöntem, ortalama \% 97.25 sinıflandırma doğruluğu ile geleneksel sinıflandırma metotları ve geleneksel ESA temelli metotla karşılaştırıldı̆̆ında üstün performans göstermiştir.

Roth ve ark. BT'den elde edilen görüntülerin ESA ile anatomik olarak sınıflandırılması için bir yöntem önermişlerdir. ESA ve veri artırımı kullanarak 1675 hasta üzerinde yaptıkları çalışmada, \% 5,9 anatomiye özel sınıflandırma hatası ve test aşamasında (AUC) 0.998 eğri altında kalan ortalama değere ulaşmışlardır. Bilgisayar destekli tanı uygulamaları için önerdikleri derin öğrenme yönteminin daha güvenilir ve daha doğru sınıflandırma konusunda geliştirilecek yöntemler için başlangıç olabileceğini belirtmişlerdir [71].

Grinsven ve ark, medikal görüntü analizi için kullanılan ESA eğitimini geliştirmek ve hızlandırmak için eğitim esnasında sınıflandırılmayan olumsuz örnekleri dinamik olarak seçecek bir yöntem önermişlerdir. Eğitim örnekleri ESA'nın güncelliğine göre sınıflandırmaya dayalı sezgisel olarak yapılandırılmıştır. Örnekler ağırlıklandırılarak, bilgi verici örneklerin bir sonraki ESA eğitim yinelemesine dâhil edilmesi sağlanmıştır. Önerilen yöntem, ESA sınıflandırılmayan olumsuz örnekleri dinamik olarak seçimi ile (SES) ve sınıflandırılmayan olumsuz örnekleri dinamik olarak seçimi olmadan (NSES) seçici örnekleme yöntemi ile eğitilmiştir. Renkli fundus görüntülerindeki kanamaların tespitine odaklandıkları çalışmada, iki insan uzman ile karşılaştırıldığında, 170 epoktan 60 epoka kadar azaltılmış bir eğitim süresi, her iki veri setinde alıı işletim karakteristiği eğrisi altında 0.894 ve 0.972 değerine sahip alanlar elde edilmiştir. SES ESA, bağımsız bir test setinde NSES ESA 'den istatistiksel olarak daha iyi performans gösterdiğini ortaya koymuşlardır [72].

Anthimopoulos ve ark. doku içindeki akciğer hastalığının modellerinin sınıflandırılması için ESA temelli bir yapı önermişlerdir. Önerilen yapı, $2 \times 2$ çekirdekli ve Leaky ReLU aktivasyonları ile 5 evrişim katmanı, bunu takiben 3 yoğunluk katmanı ve nihai özellik haritalarının boyutunu ortalama havuzlama ile boyut eşitlemeden oluşmaktadır. 120 hastaya ait olan bilgisayarlı tomografi görüntüleri ve hastanelerden türetilen 14696 görüntü yamaları ESA eğitiminde ve değerlendirilmesinde kullanılmıştır. Bu problemde kullanılan ilk derin ESA olduğunu iddia etmiş̧lerdir. Yapmış oldukları karşılaştırmalı analiz ile önerdikleri ESA ağının önceki yöntemler karşısında zorlu bir veri setinde daha etkin olduğunu ispatlamışlardır. Önerdikleri ESA modelinin \% 85,5 sınıflandırma performansına sahip ESA 'ların akciğer modellerini analiz etme potansiyelini ortaya koymuşlardır [73].

Cao ve ark, X-ray görüntülerinden tüberküloz sınıflandırması için ESA kullanmışlardır. Deneysel sonuçlar uyguladıkları ESA yaklaşımının etkinliğini göstermiştir [74].

Chen ve ark. [75] derin sinir ağını (ESA) transfer edilen bir alan oluşturarak, ABD videolarındaki fetal abdominal standart düzlemi (FASP) bulmak için öğrenmeye dayalı bir yaklaşım sunmuşlardır. Düşük seviyeli özelliklere dayanan önceki çalışmalarla karşılaştırıldığında, yaklaşımları, FASP 'ın karmaşık görünümü temsil edebileceğini ve böylece daha iyi sınıflandırma performansı 
elde edilebileceğini savunmuşlardır. Daha da önemlisi, az miktarda eğitim örneğinin neden olduğu aşırı öğrenme sorununu azaltmak için, yeni bir transfer öğrenme stratejisi önermişlerdir. Kapsamlı deneyler sonucunda yaklaşımlarının FASP lokalizasyonu için en gelişmiş yöntemlerden daha iyi performans gösterdiğini belirtmişlerdir. ESA'yı yalnızca sınırlı ABD eğitim örnekleri üzerinde eğitmişlerdir. Önerdikleri yaklaşım, derin ESA'dan faydalanırken üst düzey özellikleri temsil etmek için genellikle yetersiz eğitim örneklerinden muzdarip olan diğer benzer tıbbi görüntü hesaplama problemlerine kolayca genişletilebileceğini iddia etmişlerdir.

Shin ve ark. [76] görüntü tanımada ESA'ların kayda değer ilerlemelerinden bahsederken, tıbbi görüntüleme alanında ImageNet kadar kapsamlı bir şekilde açıklanmış veri setleri elde etmenin zorluklarından bahsetmiştir. ESA'larını tıbbi görüntü sınıflandırmada başarıyla kullanan üç ana teknik olduğunu söylemişlerdir. Bunları, sıfırdan ESA ağını eğitmek, eğitilmiş sinir ağının özelliklerini kullanmak ve denetimli ince ayarlarla denetlenmemiş ESA'nın ön eğitiminin yapılması şeklinde ifade etmişlerdir. Bununla birlikte, doğal görüntü veri setinden tıbbi görüntüler için önceden eğitilmiş ESA modellerinde ince ayar yapılması olarak bilinen transfer öğrenmesine dikkat çekmişlerdir. Yaptıkları çalışmada bilgisayar destekli algılama problemlerinin çözümü için derin ESA 'leri kullanmışlardır. Farklı ESA mimarilerini incelemişlerdir. Katman sayısına göre parametre sayılarının değiştiği incelemiş oldukları modellerin, 5000 ile 160 milyon parametre arasında değişen sayıda parametre içerdiklerini ifade etmişlerdir. Mekânsal görüntü bağlamının ve veri kümesi ölçeğinin performans üzerindeki etkisini değerlendirmişlerdir. İnce ayar kullanarak önceden eğitilmiş ImageNet ’ten ince ayar yoluyla transfer öğrenmesinin ne zaman ve neden yararlı olabileceğini incelemişlerdir. Torakoabdominal lenf nodu tespiti ve interstisyel akciğer hastalığı sınıflandırması olmak üzere iki bilgisayar destekli algılama problemi üzerinde durmuşlardır. Kapsamlı deneysel değerlendirmelerinin, ESA model analizlerinin diğer tıbbi görüntüleme görevleri için yüksek performanslı bilgisayar destekli görüntüleme sistemlerinde kullanılabileceğini öne sürmüşlerdir.

Tajbakhsh ve ark. [77] uygun bir yakınsama sağlamak için büyük miktarda etiketli eğitim verisi ve çok fazla uzmanlık gerektiren derin sinir ağının sıfırdan eğitmenin zorluğu ile ilgili soruna dikkat çekmeye çalışmışlardır. Bunun için önceden eğitilmiş derin ESA'lerin yeterli ince ayar ile sıfırdan eğitim ihtiyacını karşılayıp karşılamadığını araştırmışlardır. Bunun için üç farklı görüntüleme yönteminden sınıflandırma, tespit ve bölümleme içeren üç uzmanlıkta radyoloji, kardiyoloji ve gastroenteroloji dört ayrı tıbbi görüntüleme uygulamasını göz önünde bulundurmuşlardır.

Derin ESA'ların performansını, önceden eğitilmiş ESA'ların katman bazında ince ayarlanmış olanların performansı ile karşılaştırmışlardır. İnce ayarlı ESA'ların eğitim setlerinin boyutuna sıfırdan eğitilenlere göre daha dayanıklı olduklarını gözlemlemişlerdir. Sı ̆̆ ya da derin ayarın belirli bir uygulama için en uygun seçenek olup olmadığı ile ilgili bir sonuca varamamışlardır. Katmanlı ince ayar şemalarının, eldeki uygulama için mevcut verilere göre en iyi performansa ulaşmanın pratik bir yolunu sunabileceğini savunmuşlardır.

Yan ve ark. [78] görüntü sınıflandırması için birçok aşamadan oluşan bir derin öğrenme çerçevesi tasarlamış ve bunu vücut tanıma görüntülerine uygulamışlardır. Önerdikleri model ile görüntü sınıflandırma sorunu için ayrımcı ve bilgilendirici olmayan yerel bölgeleri keşfetmeyi ve yerel bölgelere dayalı görüntü düzeyinde bir sınıflandırıcı öğrenmesini hedeflemişlerdir. İki aşamalı öğrenme olarak tanımladıkları bu yapıda eğitim öncesi aşamada eğitim dilimlerinden en ayırt edici ve bilgilendirici olmayan yerel yamaları çıkarmak için çok örnekli bir öğrenme şeklinde ESA ağını öğretmeye çalışıı̧lardır. Yükseltme aşamasında ise önceden öğrenmiş olan ESA, görüntü sınıflandırması için bu yerel yamalar tarafindan daha da güçlendirilmiştir. Ayrımcı yerel görünümlerden yararlanarak öğretilen ESA modelinin, küresel görüntü bağlamından öğrenilenden daha doğru hale geldiğini gözlemlemişlerdir. Kullandıkları yöntemin en önemli özelliğini çok yönlü derin öğrenme yoluyla ayrımcı ve bilgilendirici olmayan yerel yamaları otomatik keşfetmesi olarak ifade etmişlerdir. Yöntemlerini sentetik bir veri seti ve büyük ölçekli bir BT veri seti ile doğrulamışlardır. Yöntemlerinin, standart derin ESA de dâhil olmak üzere, modern yaklaşımlardan daha iyi performans gösterdiğini söylemişlerdir.

Greenspan ve ark. [79] yaptıkları çalışmada derin öğrenmenin desteklediği teknoloji ve uygulamaları incelemişlerdir. ESA'lerin çok çeşitli bilgisayarlı görme görevlerindeki başarılarına dikkat çekmişlerdir. Derin ESA'ların ham verilerden otomatik olarak elde edilen orta seviye ve yüksek seviye soyutlamaları öğrendiklerini söylemişlerdir. Sonuç olarak ESA'ların vasıtasıyla oluşturulan tanımlayıcıların doğal görüntülerde nesne tanıma ve yerelleştirmede son derece etkili olduğunu ifade etmişlerdir. Tıbbi görüntü analizinde de her geçen gün ESA ve derin öğrenme yöntemlerinin kullanımının arttığını belirtmişlerdir.

Cheng ve ark [80] sınır bölümlendirmesi gibi yanlış görüntü işleme sonuçlarının neden olduğu olası hataları önleyerek, benign ve malign nodüllerin ve lezyonların ayırıı tanısı için derin öğrenmeye dayalı bilgisayar destekli tanı (CADx) hakkında kapsamlı bir çalışma gerçekleştirmişlerdir. Çoğu geleneksel CADx algoritmasında olduğu gibi, daha az dayanıklı bir özellik setinden kaynaklanan sınıflandırma yanlılığının önüne geçmeye çalışmışlardır. Yığın gürültü arındırıcı oto-kodlayıcıyı (SDOK), meme ultrason lezyonları ve akciğer BT nodüllerindeki farklıları incelemek için kullanmışlardır. SDOK mimarisini, otomatik özellik arama mekanizması ve gürültü toleransı avantajı ile donatmışlardır. SDOK tabanlı CADx 'in konvansiyonel şemaya göre üstünlüğünü göstermek için diğer CADx algoritmaları ile karşılaştırmışlardır. 10 kat çapraz doğrulama yaptıkları SDOK tabanlı CADx algoritmasının iki geleneksel yöntem üzerinde önemli artış gösterdiğini ifade etmişlerdir. Sonuç olarak, derin öğrenme tekniklerinin, CADx sistemlerinin tasarım paradigmasını açık tasarım ve problem odaklı özelliklerin seçilmesine gerek kalmadan değiştirebileceğini söylemişlerdir.

Kondo ve ark. [81] temel bileşen regresyon analizi kullanarak, çok katmanlı Grup verisi işleme yöntemini (GMDH) içeren sinir ağı algoritmasını, karaciğer ve dalak gibi organları tanıma problemlerine uygulamışlardır. Temel bileşen regresyon analizini birçok gizli katmanı olan derin sinir ağındaki ağılıkların öğrenme algoritması olarak kullanmışlardır. Derin sinir ağının birçok gizli katmana sahip mimarisini, Akaike 'nin bilgi kriteri (AIC) veya Tahmin Edilen Kareler Toplamı (PSS) olarak tanımlanan tahmin hata kriterini en aza indirgemek için sezgisel özyönetim metodunu kullanarak otomatik olarak düzenlemişlerdir. Sezgisel özyönetim metodunu evrimsel hesaplamanın bir türü olarak belirtmişlerdir. Sinir ağının mimarisinin birçok gizli katmana sahip olmasının, GMDH tipi sinir 
ağında birçok eş doğrusallık oluşmasına neden olduğunu ve bunun da tahmin değerlerini kararsızlaştırdığını ifade etmişlerdir. Ancak yaptıkları çalışmada oluşturdukları GMDH tipi sinir ağlarında çok eş doğrusallığın oluşmadığını ve böylece daha kararlı ve daha doğru tahmin değerleri elde ettiklerini belirtmişlerdir. Önerdikleri bu yeni algoritmayı, karaciğer ve dalağın tıbbi görüntü tanımalarına uygulamışlardır. Karaciğer ve dalak bölgelerinin organize GMDH tarafından otomatik olarak tanındığını ve çıkarıldığını belirtmişlerdir. Tanıma sonuçlarını, geri yayılma yöntemi kullanılarak eğitilmiş geleneksel sigmoid fonksiyonlu sinir ağları ile karşılaştırmışlardır. Uyguladıkları GMDH tipi sinir ağları yönteminin abdominal çoklu organların tıbbi görüntülerinin tanınmasındaki problemlerin çözümüne katkıda bulunabileceğini ifade etmişlerdir.

Diğer bir çalışmada ise Kondo ve ark. [82] GMDH tipi sinir ağlarını, temel bileşen regresyon analizini kullanılarak kalp bölgelerinin tıbbi görüntü tanımalarına uygulamışlardır. GMDH tipi sinir ağının, kalp bölgelerinin tıbbi görüntü tanımasında faydalı olduğunu göstermişlerdir. Bununla birlikte derin GMDH tipi sinir ağı ile sağ ve sol böbreklerin 3 boyutlu tıbbi görüntü tanımasını [83] yapmışlar ve akciğer kanserinin derin geribildirim GMDH tipi sinir ağı ile tıbbi görüntü teşhisindeki başarısını da göstermişlerdir [84].

Rose ve ark. [85] Derin katmanlı kümeleme yöntemi kullanarak mamografi görüntülerini analiz etmişlerdir. Bu çalışmada, bir radyoloğun dikkatini gerektiren ilgili bölgeleri güvenilir bir şekilde etiketlemek amacıyla bilgisayar destekli tespit için mamogramları bölümlere ayırarak incelemişlerdir. Sınıflandırma, standart bir ileri beslemeli sinir ağı ile birlikte derin bir öğrenme mimarisinin denetimsiz kümelenmesi olan yapı taşları kullanılarak yapılmıştı. Elde ettikleri sonuçlara göre, 0,96 görüntü başına yama duyarlılığı ve 0,99 özgüllüğü ile minimum görüntü özelliklerini kullanarak yüksek boyutlu verileri işleyen bir sınıflandırma aracının oluşturula bilineceğini ifade etmişlerdir.

Zhou ve ark. [86] hiperspektral görüntülerin (HSI) sağlam özelliklerini elde etmek için bir spektral-uzaysal özellik öğrenmesi (SSFL) yöntemi önermişlerdir. SSN' in spektral ve mekânsal özellik öğrenme operasyonları arasında geçiş yaparak faydalı yüksek seviye özellikleri öğrendiğini ve daha sonra çekirdek tabanlı aşırı öğrenme makinesinin (KELM), görüntü piksellerini sınıflandırmak için SSN 'ye yerleştirildiğini belirtmişlerdir. SSN 'nin etkinliğini doğrulamak için iki temel HSI veri setinde kapsamlı deneyler gerçekleştirmişlerdir. Modern yöntemlerle karşılaştırıldığında, derin bir hiyerarşik yapıya sahip SSN 'nin, özellikle eğitim örneklerinin sayısı az olduğunda, genel doğruluk, ortalama doğruluk ve kappa (к) katsayısı bakımından daha yüksek sınıflandırma doğruluğu elde ettiğini göstermişlerdir.

Lerouge ve ark. [87] görüntü etiketleme problemini çözmek için Girdi çıkışı derin mimari (IODA) adı verilen derin bir sinir ağı (DSA) mimarisi önermişlerdir. IODA 'nın bütün bir görüntüyü etiketli bir haritanın tamamına doğrudan bağladığını ve tek bir sinir ağı ileri adımı kullanarak her piksele bir etiket atadığını belirtmişlerdir. IODA 'nın özgünlüğünü, DSA giriş ön eğitim öncesi kolaylığını, etiketlerin üst düzey bir gösterimini öğrenmek için çıkış alanına aktarmak olarak ifade etmişlerdir. Özellik tasarımı veya çıkış kodlaması gibi herhangi bir ön işlemeye gerek kalmadan, IODA 'nın tam bir sinir ağı çerçevesi içinde hızlı bir görüntü etiketlemesi sağladığını söylemişlerdir.

Wang ve ark. [88] uçtan uca kas ve dağınık bölgeleri tanımlamak için tamamen Evrişimli ağlara (FCN) dayanan yeni bir derin sinir ağı önermişlerdir. İlk olarak, derin sinir ağını eğitmek için sınırlı tıbbi eğitim verisine sahip olmanın zorluklarını ele almışlardır. İkincisi, büyük ölçüde farklı boyutlarda ve keyfi şekillerde hedef bölgeleri ele almak için, önerdikleri derin sinir ağının çok ölçekli bilgileri ve yapısal bilgileri araştırmasını sağlamışlardır. Klinik görüntüler üzerinde yapılan deneysel sonuçlar, yaklaşımlarının, kas ve dağınık bölgelerin semantik bölümlenmesi için son teknoloji FCN 'den daha iyi performans gösterdiğini kanıtlamışlardır. Önerdikleri yöntemin çeşitli tıbbi görüntüleme uygulamalarındaki diğer bölgeleri tanımlamak için kolayca genişletilebileceğini iddia etmişlerdir.

\subsubsection{Medikal Bilişimde Kullanılan Derin Öğrenme Yöntemleri}

Hastalık tahmini, insan davranışı izleme, veri madenciliği derin öğrenme yöntemlerinin kullanıldığı medikal bilişim uygulamalarıdır. Tablo 4 ‘te Medikal bilişim alanında kullanılan derin öğrenme yöntemleri ve uygulandıkları alanlar gösterilmiştir.

Tablo 4. Medikal bilişimde kullanılan derin öğrenme uygulamaları

\begin{tabular}{c|c}
\hline Medikal Bilişim Uygulamaları & Uygulanan Derin Öğrenme Metotları \\
\hline Hastalık tahmini & Derin inançă̆ları \\
İnsan davranışı izleme & Evrişimli sinir ağları \\
Veri madenciliği & Yinelemeli sinir ăglarl \\
& Evrişimli derin inançağlart \\
& Derin sinir ă̆lart \\
\hline
\end{tabular}

$\mathrm{X}$ Che ve ark. [89] derin öğrenme modellerinin performansını taklit ederken sağlam bir tahmin yapmak için yorumlanabilir fenotip özelliklerini öğrenmede yorumlanabilir mimik öğrenme adı verilen yeni bir bilgi damıtma yaklaşımını ortaya koymuşlardır. Çerçeveleri, yı̆̆ın gürültü arındırıcı otomatik kodlayıcı ve uzun kısa süreli bellek gibi derin öğrenme modellerinden yorumlanabilir özellikleri öğrenmek için gradyan ile güçlendirilmiş ağaçları kullanmaktadır. Gerçek dünyadaki klinik zaman serisi veri setindeki kapsamlı deneylerin, yöntemlerinin derin öğrenme modellerinden daha iyi performans elde ettiğini ve klinik karar vermede yorumlanabilir fenotipler sağladığını belirtmiş̧lerdir.

Miotto ve ark. klinik tahminsel modellemeyi çabuklaştıran, elektronik hasta kayıtlarından oluşan verilerden genel bir hasta temsili elde etmek için, danışmansız derin özellik öğrenme yöntemini önermişlerdir. New York 'da bulunan Mount Sınai hastanesine ait veri ambarındaki 700.000 hastanın elektronik hasta kayıt verilerinin hiyerarşik düzenlerini ve bağımlılıklarını yakalayacak şekilde 3 katmanlı gürültü temizleyen oto-kodlayıcı yı̆̆ınını kullanmışlardır. Hastaların çeşitli hastalıklara yakalanma ihtimalini e-ISSN: 2148-2683 
değerlendirerek sağlık durumlarını geniş ölçüde öngören sonuçları "derin hasta" olarak adlandırdıkları bir gösterim ile ifade etmişlerdir. Farklı klinik alanlardan ve geçici gözetimden 76214 hasta üzerinde 78 hastalık içeren test gerçekleştirmişlerdir. Şiddetli diyabet, şizofreni ve çeşitli kanser hastalıklarının tahmininde daha iyi performans gösteren yöntemleri klinik karar destek sistemlerinin klinik tahminlemenin geliştirilmesinde katkı yapacağını göstermişlerdir [90].

Nie ve ark. [91] seyrek derin öğrenme ile sağlıkla ilgili sorulardan hastalık çıkarımı yapmak için derin öğrenme yöntemlerini kullanmışlardır. Çevrimiçi doktorlar tarafından etiketlenen gerçek dünya veri setinde yapılan kapsamlı deneyler ile kullandıkları yöntemin önemli performans kazanımları olduğunu göstermişlerdir.

Mehrabi ve ark. [92] Rochester Epidemiyoloji projesi verileri üzerinde geçici desen keşfi için derin bir öğrenme algoritması geliştirmişlerdir. Her hastanın kayıtlarını ICD9 ve HCUP CSS tanı kodları ile geçici klinik olayların bir matrisi olarak modellemişler ve tanı kodlarını satırlar olarak ve tanı yıllarını da sütunlar olarak göstermişlerdir. Tanı anında 18 veya daha küȩük yaştaki hastaları seçmişlerdir. Her hastanın teşhis matrisi değerleri kullanılarak, görünür düğümlü üç derin katmana sahip derin bir Boltzmann makinesi oluşturmuşlardır. Modelin son ağılıkları, hasta kayıtları arasında ortak özellikler olarak analiz edilmiştir.

Shin ve ark. [93] Ulusal bir araştırma hastanesinin resim arşivleme ve iletişim sisteminden radyoloji görüntülerinin semantik etkileşimlerini çıkarmak ve raporlamak için harmanlanmış bir metin ve resim derin öğrenme sistemi ortaya koymuşlardır. Doğal dil işleme ile klinisyenler tarafından tanısal referans için seçilen temsili $\sim 216 \mathrm{~K}$ iki boyutlu anahtar imge koleksiyonunu oluşturmuşlar ve görüntüleri otomatik olarak açıklamalarıyla eşleştirmişlerdir. Oluşturdukları model, anlamsız etiketler üretmek ve bunları bir görüntü verisi olarak öngörmek için, belge ve cümle düzeyinde metin koleksiyonlarında denetlenmeyen öğrenme ile denetimli öğrenme arasında birleştirmişlerdir. Taranan hastaya ait görüntüde radyoloji seviyesinde anlamsal bir tahmin yapıldığını ve bununla ilişkili anahtar kelimelerin oluşturulduğunu belirtmişlerdir. Daha belirleyici bir hasta taraması için bir dizi sık hastalık tipi üzerinde durmuşlardır. Bunun, çoğu modern klinik kurumda bulunan elektronik hasta kayıtlarından büyük ölçekli öğrenmenin gerçekleştirilebileceğini ve hastalıkların tahmini için faydalı olabileceğini belirtmişlerdir.

Lipton ve ark. [94] yoğun bakım ünitesinde (YBÜ) klinik tıbbi verileri çok değişkenli zaman serileri olarak ifade etmişlerdir. Her hasta ziyareti için, sensör verileri ve laboratuvar test sonuçlarını hastanın Elektronik sağlık kayıtlarına (EHR) kaydetmişlerdir. Bu kayıtların birçok bilgiyi içerdiğini ancak değişken uzunluk, düzensiz örnekleme ve eksik verilerden dolayı verilerin etkili bir şekilde benimsenmesinin zor olduğunu söylemişlerdir. Tekrarlayan Sinir Ağlarından (YİSA 'ler), Uzun kısa süreli bellek (LSTM) gizli birimlerini kullananların, dizi verilerinden öğrenmede güçlü ve giderek daha popüler hale gelen modeller olduklarını söylemişlerdir. $\mathrm{Bu}$ modellerin değişken uzunluktaki dizilerin etkin bir şekilde modellenmesinde ve uzun mesafeli bağımlılıkları elde etmedeki başarılarından söz etmişlerdir. Çalışmalarının, LSTM 'lerin çok değişkenli klinik ölçüm serilerindeki kalıpları tanıma yeteneğini deneysel olarak değerlendirmede ilk olduğunu iddia etmişlerdir. Spesifik olarak, 13 örnek üzerinde 128 tanıyı sık sık fakat düzensiz örneklenmiş klinik ölçümleri sınıflandırmak için bir model eğiterek tanıların çok etiketli sınıflandırma elde etmeye çalışmışlardır. İlk önce, klinik verilerin modellenmesinde basit bir LSTM ağının etkinliğini belirlemişler. Daha sonra, her adımda hedefleri çoğalttıkları basit ve etkili bir eğitim stratejisi benimsemişlerdir. Yalnızca ham zaman serilerinde eğittikleri modellerinin diğer yöntemlerden daha iyi performans gösterdiğini iddia etmişlerdir.

Liang ve ark. sağlık hizmetlerinde kullanılan bilgisayar destekli kural tabanlı karar destek sistemlerinin yetersiz olduğunu öne sürmüşlerdir. Bunun yerine Evrişimli derin inanç ağlarından oluşan bir yöntem önermişlerdir. Yöntemlerini, Çin'de elektronik hasta kayıtlarından manuel olarak dönüştürülmüş medikal teşhis verilerinden ve hipertansiyon verilerinden oluşan geniş ölçekli bir veri seti ile eğitmişlerdir. Deneysel sonuçlar, önerdikleri modelin daha önce bilinmeyen kavramları ortaya koyabildiğini ve geleneksel modellerden daha iyi performans gösterdiğini söylemişlerdir [95].

Putin ve ark. [96] değişken derinlikli, yapı ve optimizasyona sahip 21 adet DSA içeren modüler bir yapı tasarlayarak temel bir kan testiyle insanın kronolojik yaşını tahmin etmeye çalışmışlardır. DSA 'leri eğitmek için ortak kan biyokimyasından 60.000'den fazla örnek ve tek bir laboratuvar tarafından yapılan ve kronolojik yaş ve cinsiyete bağlı rutin sağlık muayenelerinden hücre sayımı testlerini kullanmışlardır. Oluşturdukları yapıda en iyi performans gösteren DSA, 10 yıllık bir çerçevede kronolojik yaşı tahmin ederken \% 81,5 doğruluk değerine sahip ve 10 yıllık bir çerçeve içinde kronolojik yaş1 öngörürken, tüm yap $\%$ 83,5 doğruluk değerini elde etmiş̧ir. Oluşturdukları model, aynı zamanda insanın kronolojik yaşını tahmin etmek için en önemli 5 işaretleyici belirlemişlerdir. Bunları; albümin, glukoz, alkalen fosfataz, üre ve eritrositler olarak tanımlamışlardır. Model yapılarının, kronolojik yaş ve cinsiyete bağlı çok modlu verilerin entegrasyonunu kolaylaştırabileceğini; bunun da insanlarda yaşlanmanın bütünleşmiş biyobelirteçlerini izlemek ve türler arasındaki farklı özelliklerin test edilmesini izlemek için basit, minimal invaziv ve uygun maliyetli yöntemlerin oluşmasını sağlayabileceğini savunmuşlardır.

Futoma ve ark. [97] erken hastane geri kabullerini tahmin etmek için daha önce uygulanmamış ve tipik olarak sağlık literatüründe uygulanan regresyon yöntemlerinden daha iyi performans gösteren birkaç öngörücü modeli açıklamışlar ve bunları karşılaştırmışlardır. Yalnızca ICD kodlarını ve birkaç arka plan değişkenini kullanarak hasta geri kabul riskini değerlendirmede kullanılan modeller oluşturmak için genel bir çerçeveyi vurgulamışlardır. Önerdikleri yöntemi literatürdeki diğerleriyle karşılaştırarak rastgele ormanlar, cezalandırılmış lojistik regresyonlar ve derin sinir ağlarının daha önce bu soruna uygulanan diğer yöntemlerden anlamlı olarak daha iyi tahmine dayalı performans gösterdiğini savunmuşlardır.

Zhao ve ark. Parkinson hastalığının şiddetinin yürüme bilgisinden, özellikle de ayak sensörleri tarafından kaydedilen Dikey Zemin Reaksiyon Kuvveti'nin (VGRF) ardışık verilerinden otomatik olarak derecelendirilmesi için yürüyüş verilerinin ardındaki zamansal kalıpları öğrenmek için LSTM ve ESA'i birleştiren iki kanallı bir model geliş̧irmişlerdir. Oluşturdukları modeli kamuya ait üç VGRF veri kümesi ile eğitmiş ve test etmişlerdir. Önerdikleri modelin iyi eğitildikten sonra, öngörülen şiddet, herhangi bir öznellik endişesini çözen sensör verilerinden doğrudan elde edilebileceğini savunmuşlardır. Bunun tanı prosedürünü basitleştirdiğini ve daha 


\section{Avrupa Bilim ve Teknoloji Dergisi}

fazla kişiselleştirilmiş tedavi sağladığı için beyin cerrahlarına yarar sağlayacağını iddia etmişlerdir. Önerdikleri LSTM modelinin daha fazla veri türünü barındırmak için geliştirilebileceğini, Parkinson hastalığının şiddet düzeylerinin tahmin doğruluğu açısından mevcut olanlardan daha iyi performans gösterdiğini ve Parkinson hastalığının klinik teşhisine katkıda bulunacağını belirtmişlerdir [98].

Purushotham ve ark. 2001 - 2012 yılları arasında, Beth Israel Deaconess Tıp Merkezi'nde yoğun bakım ünitesine kabul edilen tüm hastaları kapsayan (MIMIC-III) kamuya açık veri setini kullanarak mortalite ve yatış süresi için Derin öğrenme modellerinin tahmin performansını incelemişlerdir. Çalışmalarında YISA temelli bir yapı önermişlerdir. Elde ettikleri sonuçların, derin öğrenme modellerinin, özellikle "ham" klinik zaman serisi verilerinin modellere girdi özellikleri olarak kullanıldığında, diğer tüm yaklaşımlardan tutarlı bir şekilde daha iyi performans gösterdiğini belirtmişlerdir [99].

Davoodi ve Moradi, yoğun bakım ünitelerinde mortalite tahmini için Derin Kural Tabanlı Bulanık Sınıflandırıcı (DRBFS) modelini önermişlerdir. DRBFS'de, her bir ünitedeki gizli katman, yorumlanabilir bulanık kurallarla temsil edilmektedir. Yığın yaklaşımına göre, aynı giriş alanı DRBFS'nin her temel yapı biriminde tutulmaktadır. Mevcut ana birimin tahmin sonuçlarının rasgele çıkarımlarından elde edilen rasgele kaymalara ek olarak verilen eğitim, bir sonraki ana yapı biriminin girdisi olarak sunulmaktadır. MIMIC-III veri setinden belirlenen 10972 erişkin hastaların\% 9,31’i hastanede ölmüştür. Yoğun bakım ünitesinin ilk 48 saatindeki heterojen özellik seti hastane içi mortalite oranı için çıkarılmıştır. Önerdikleri modelde Naive Bayes (NB), Karar Ağaçları (DT), Gradyan Arttırma (GB) gibi birçok sınıflandırıcıyı değerlendirmişlerdir. Elde ettikleri sonuçlar DRBFS'nin, yorumlanabilir kural tabanlarını korurken çeşitli yöntemleri geride bıraktığını göstermiştir. Ayrıca, belirli kümeleme yöntemlerinden faydalanan DRBFS 'in büyük heterojen veri kümeleri için iyi ölçeklendirilebileceğini belirtmişlerdir [100].

Supratak ve ark. Biyomedikal uygulamalarda farklı tiplerdeki biyo-işaretler ve sinyallerden özelliklerin çıkarılmasında SAE, ESA ve YISA 'in kullanımlarını incelemişlerdir[101].

Pereira ve ark. el yazısı görüntülerden özelliklerin öğrenilmesi için ESA kullanmışlardır. Ek olarak, bilgisayar destekli Parkinson hastalığı teşhisi ile ilgili araştırmayı desteklemek için görüntülerden ve sinyal tabanlı verilerden oluşan bir veri seti hazırlamışlardır. Önerdikleri yaklaşım, ham veriler ve doku temelli tanımlayıcılarla karşılaştııılmış, temel olarak erken aşama tespiti bağlamında \% 95'e varan sonuçlar elde etmişlerdir. Elde edilen dinamiğin derin öğrenme teknikleri kullanılarak analizi, otomatik Parkinson hastalığı tanımlaması için yararlı olduğu kadar el yazısı özelliklerin çıkarımında daha iyi performans gösterdiğini ifade etmişlerdir[102].

Wulsin ve ark. beyin işlevleri ile ilgili klinik EEG dalga formlarından anomali tespiti için yarı-danışmanlı DSA kullanmışlar ve uyguladıkları yöntemin SVM 'den daha başarılı sonuçlar verdiğini iddia etmişlerdir [103].

Hu ve ark. beyin hastalıklarının teşhisinde ve klinik karar desteği sağlamada derin öğrenmenin avantajlarını göstermek için Alzheimer hastalığını çalışmalarında örnek olarak kullanmışlardır. Öncelikle, ham fMRG 90 beyin bölgesine ait aktiviteleri temsil eden bir matrise dönüştürmüşlerdir. Daha sonra, farklı beyin bölgeleri arasındaki fonksiyonel bağlantıyı göstermek için her bir beyin bölgesi çifti arasındaki korelasyonun hesaplanmasıyla bir korelasyon matrisi oluşturmuşlardır. Sonraki aşamada da, Alzheimer hastalığına duyarlı bir korelasyon matrisini sınıflandırmak için Oto-kodlayıcı (AE) bir ağ oluşturmuşlardır. Hastalık tahmini ile ilgili deneysel sonuçlar kullandıkları yöntemin geleneksel yöntemlere göre daha başarılı olduğunu göstermiştir. Alzheimer hastalığının tahmininde güçlü bir referans sağlayan yöntemleri SVM ile karşılaştırıldığında tahmin doğruluğunda yaklaşık \% 25 gelişme gösterdiğini gözlemlenmişlerdir [104].

Pang ve ark. [105] biyomedikal görüntülerin uçtan uca sınıflandırılması için, yüksek stabilite ve kesin doğruluk oranına sahip, derin ESA'ye dayanan bir derin öğrenme yaklaşımı önermişlerdir. Derin bir model oluşturmak için etki alanı aktarılmış derin ESA uygulamışlar ve ardından, denetimli eğitimi kullanarak orijinal biyomedikal görüntülerin ham piksellerine dayanan genel bir derin öğrenme mimarisi geliştirmişlerdir. Modellerinde, özellik alanının manuel tasarımına ihtiyaç duymamışlardır. Sınıflandırıcılarını, kamuya ait biyomedikal veri setlerinde değerlendirmişler ve son teknoloji yaklaşımlarla karşılaştırmışlardır. Önerdikleri modelin biyomedikal görüntüler için sağlam ve otomatik olarak uçtan uca sınıflandırmada başarılı olduğunu belirtmişlerdir.

\section{Sonuç}

Sağlık alanında hastalıkların erken tanısında makine öğrenmesi yöntemlerinin kullanımı artmıştır. Biyomedikal, sağlık biyoinformatiği ve medikal görüntüleme makine öğrenmesi yöntemlerinin en popüler olduğu alanlardandır. Farklı ağ mimarileri ve öğrenme algoritmaları ile büyük verinin analizinde başarılı olan derin öğrenme yöntemleri sağlık alanında da hem hastalıkların erken tanısında hem de hastalığın erken tedavisinde sağlık çalışanlarına yardımcı olacağı görülmektedir. Sağlık alanında bu yöntemlerin kullanılması ölümcül sonuçlara yol açan süreçlerin önceden tahmin edilmesinde ve hastalığın hangi evrede olduğunun belirlenebilmesi için faydalı olacağı düşünülmektedir. Bununla birlikte derin öğrenme yöntemlerinin hala birçok alanda genelleştirilerek kullanımı mümkün değildir. Elbette ki bunda daha önce kullanılan yöntemlere olan güven ve derin öğrenme yaklaşımının birçok alanda olduğu gibi sağlık alanında da tam olarak bilinmemesinden dolayı benimsenmemesi olarak ön plana çıkmaktadır. Bazı araştırmalar derin öğrenme yöntemlerini aldatmacadan ibaret olarak görmekte iken diğerleri ise derin öğrenme için çok büyük veriye ihtiyaç olduğunu ve öğrenme modelinin veriye göre uyarlanmasının uygulanan modelin başarısını etkilediğinden bahsetmektedirler. Bu çalışmada derin öğrenme yaklaşımlarının sağlık alanındaki uygulamaları incelenmiştir. Tüm ön yargılara ve elde edilen başarılı sonuçlara rağmen derin öğrenmenin sağlık alanında başarılı olabilmesi için veriye göre uygun model yaklaşımının benimsenmesinin ve farklı derin öğrenme mimarilerinin sağlık alanında kullanımının artmasına bağlı olduğunu söyleyebiliriz. Bu alanda yapılacak çalışmalarda da matematiksel modellemenin önemine vurgu yapmaktayız. Derin öğrenme mimarilerinin temelindeki matematiksel modellemeler ne kadar iyi anlaşılırsa gelecekte de derin öğrenme yöntemleri o kadar başarılı olacaktır. 


\section{Kaynakça}

[1] Kaya U., Yilmaz A. (2019). Derin Öğrenme, 1-2, ISBN:978-605-2118-399.

[2] Buduma, N. (2015). Fundamentals of deep learning, Copyright (C) 2015 Nikhil Buduma. All rights reserved. Printed in the United States of America. Published by O’Reilly Media, Inc., 1005 Gravenstein Highway North, Sebastopol, CA 95472. November 2015, First edition.

[3] Ravì, D., Wong, C., Deligianni, F., Berthelot, M., Andreu-Perez, J., Lo, B., Yang, G. Z. (2017). Deep learning for health informatics, in IEEE Journal of Biomedical and Health Informatics, 21(1), 4-21.

[4] Hinton, G. E., Salakhutdinov, R. R. (2006). Reducing the dimensionality of data with neural networks, Science, 313(5786), 504507.

[5] Ranzato, M., Poultney, C., Chopra, S., LeCun, Y. (2007). Efficient learning of sparse representations with an energy-based model, Advances in Neural Information Processing Systems (NIPS 2006), MIT Press, 1137-1144.

[6] Vincent, P., Larochelle, H., Bengio, Y., Manzagol, P. A. (2008). Extracting and composing robust features with denoising autoencoders, ICML '08 Proceedings of the 25th international conference on Machine learning, Helsinki, Finland, $1096-1103$.

[7] Rifai, S., Vincent, P., Muller, X., Glorot, X., Bengio, Y. (2011). Contractive auto-encoders: Explicit invariance during feature extraction, in Proceedings of the 28 th International Conference on Machine Learning, Bellevue, WA, USA, 833-840.

[8] Masci, J., Meier, U., Cireşan, D., Schmidhuber, J. (2011). Stacked Convolutional Auto-Encoders for Hierarchical Feature Extraction, Artificial Neural Networks and Machine Learning - ICANN 2011, Lecture Notes in Computer Science, Springer, Berlin, Heidelberg, 6791, 52-59.

[9] Hinton, G. E. , Osindero, S., Teh, Y. W. (2006). A fast learning algorithm for deep belief nets, Neural Comput., 18(7), 1527-1554.

[10] Salakhutdinov, R., Hinton, G. E. (2009). Deep Boltzmann machines, in Proceedings of the 12th International Confe-rence on Artificial Intelligence and Statistics (AISTATS) 2009, Clearwater Beach, Florida, USA, 1, 3.

[11] Younes, L. (1999). On the convergence of markovian stochastic algorithms with rapidly decreasing ergodicity rates, Stochastics: An Int. J. Probab. Stochastic Process, 65, 177-228.

[12] Williams, R. J., Zipser, D. (1989). A learning algorithm for continually running fully recurrent neural networks, Neural Comput, 1(2), 270-280.

[13] LeCun, Y., Bottou, L., Bengio, Y., Haffner, P. (1998). Gradient-based learning applied to document recognition, in Proceedings of the IEEE, 86(11), 2278-2324.

[14] Hubel, D. H., Wiesel, T. N. (1962). Receptive fields, binocular interaction and functional architecture in the cat's visual cortex, J. Physiol, 160(1), 106-154.

[15] Krizhevsky, A., Sutskever, I., Hinton, G. E. (2017). Imagenet classification with deep convolutional neural networks, Communications of the ACM, New York, NY, USA, 60(6), 84-90.

[16] Szegedy, C. et al. (2015). Going deeper with convolutions, 2015 IEEE Conference on Computer Vision and Pattern Recognition (CVPR), Boston, MA, 1-9.

[17] http://www.iro.umontreal.ca/ pift6266/H10/notes/mlintro.html, ( Erişim tarihi: 13.03.2019).

[18] Hinton, G. E., Osindero, S., Teh Y., (2006). A fast learning algorithm for deep belief nets, Neural Computation, 18, $1527-1554$.

[19] Bengio, Y., Lamblin, P., Popovici, D., Larochelle, H. (2007). Greedy layer-wise training of deep networks, in J. Platt et al. (Eds), Advances in Neural Information Processing Systems 19 (NIPS 2006), MIT Press, 153-160.

[20] Hinton, G. E., Salakhutdinov, R. R. (2006). Reducing the dimensionality of data with neural networks, Science, 313(5786), 504507.

[21] Salakhutdinov, R. R., Hinton, G. E. (2007). Learning a nonlinear embedding by preserving class neighbourhood structure, Journal of Machine Learning Research - Proceedings Track, 2, 412-419.

[22] Le Roux, N., Bengio, Y. (2008). Representational power of restricted Boltzmann machines and deep belief networks, Neural Comput., 20(6), 1631-1649.

[23] Sutskever, I., Hinton, G. E. (2008). Deep, narrow sigmoid belief networks are universal approximators, Neural Comput., 20(11), 2629-2636.

[24] Ranzato, M., Huang, F.J., Boureau, Y., LeCun, Y. (2007). Unsupervised learning of invariant feature hierarchies with applications to object recognition, 2007 IEEE Conference on Computer Vision and Pattern Recognition, Minneapolis, MN, 1-8.

[25] Suwajanakorn, S., Seitz, S. M., Kemelmacher-Shlızerman, I. (2017). Synthesizing Obama: Learning Lip Sync from Audio, ACM Trans. Graph. journal, New York, USA, 36(4).

[26] Dahl, R., Norouzi, M., Shlens, J. (2017). Pixel recursive super resolution, CoRR journal, abs/1702.00783.

[27] Cao, Z., Simon, T., Wei, S. E., Sheikh, Y. (2016). Realtime multi-person 2d pose estimation using part affinity fields, CoRR,abs/1611.08050.

[28] Karpathy, A., Li, F. F. (2014). Deep visual-semantic alignments for generating image descriptions", CoRR, abs/1412.2306.

[29] Ganin, Y., Ustinova, E., Ajakan, H., Germain, P., Larochelle, H., Laviolette, F., Marchand, M., Lempitsky, V. (2016). Domainadversarial training of neural networks, Journal of Machine Learning Research, 59, 1-35.

[30] http://www.deepglint.com/skill?pageState=\%27intelligentAlgorithm\%27, (Erişim tarihi: 19.03.2019)

[31] Nguyen, A. M., Dosovitskiy, A., Yosinski, J., Brox, T., Clune, J. (2016). Synthesizing the preferred inputs for neurons in neural networks via deep generator networks", CoRR, abs/1605.09304.

[32] Radford, A., Metz, L., Chintala, S. (2015). Unsupervised representation learning with deep convolutional generative adversarial networks, CoRR, abs/1511.06434.

[33] Reiman, D. M., Göhre, B. E. (2019). Deblending galaxy superpositions with branched generative adversarial networks", 10.1093/mnras/stz575, Monthly Notices of the Royal Astronomical Society, 2(485), 2617-2627. 


\section{Avrupa Bilim ve Teknoloji Dergisi}

[34] Wu, Y., Schuster, M., Chen, Z. et al. (2016). Google's neural machine translation system: bridging the gap between human and machine translation, CoRR, abs/1609.08144.

[35] Kuang, Y. (2019). Deep neural network for deep sea plankton classification, Stanford University, http://cs231n.stanford.edu/reports/2015/pdfs/ymkuang_project.pdf.

[36] Al-Barazanchi, H. A., Verma, A., Wang, S. (2019). Plankton image classification using convolutional neural networks, Department of Computer Science, California State University, Fullerton, CA, USA,https://pdfs.semanticscholar.org/ed26/f44893b2e53147ca86b4e7bfaa1eeeb9832f.pdf.

[37] Yan, J., Li, X., Cui, Z. (2017). A more efficient ESA architecture for plankton classification, From book Computer Vision: Second CCF Chinese Conference, CCCV 2017, Tianjin, China, Proceedings, Part III, 198-208.

[38] Classifying plankton with deep neural networks. (2015). http://benanne.github.io/2015/03/17/plankton.html.

[39] Isola, P., Zhu, J. Y., Zhou, T., Efros, A.A. (2016). Image-to-image translation with conditional adversarial networks, CoRR, abs/1611.07004.

[40] http://www.robots.ox.ac.uk/ vgg/projects.html. (Erişim tarihi: 23.03.2019).

[41] Mnih, V., Kavukcuoglu, K., Silver, D., Graves, A., Antonoglou, I., Wierstra, D., Riedmiller, M. A. (2013). Playing atari with deep reinforcement learning, CoRR, abs/1312.5602.

[42] Huval, B., Wang, T., Tandon, S., Kiske, J., Song, W., Pazhayampallil, J., Andriluka, M., Rajpurkar, P., Migimatsu, T., ChengYue, R., Mujica, F. A., Coates, A., Ng, A. Y. (2015). An empirical evaluation of deep learning on highway driving, CoRR, abs/1504.01716.

[43] Levine, S., Pastor, P., Krizhevsky, A., Ibarz, J., Quillen, D. (2018). Learning hand-eye coordination for robotic grasping with deep learning and large-scale data collection, The International Journal of Robotics Research, 37(4-5), 421-436.

[44] Yu, J., Weng, K., Liang, G. et al. (2013). A vision-based robotic grasping system using deep learning for 3D object recognition and pose estimation, Robotics and Biomimetics (ROBIO), 2013 IEEE International Conference on; Shenzhen, 1175-1180.

[45] Zhou, Y., Ebrahimi, S., Arik, S.Ö., Yu, H., Liu, H., Diamos, G. (2018). Resource-efficient neural architect, CoRR, abs/1806.07912, 1806-07912.

[46] Li, X., Xiong, H., Wang, H., Rao, Y., Liu, L., Huan, J. (2019). Delta: deep learning transfer using feature map with attention for convolutional networks, CoRR, abs/1901.09229.

[47] Gebru, T., Krause, J., Wang, Y., Chen, D., Deng, J., Aiden, E.L., Fei-Fei, L. (2017). Using deep learning and Google Street View to estimate the demographic makeup of neighborhoods across the United States, Proceedings of the National Academy of Sciences Dec 2017, 114 (50), 13108-13113.

[48] Fakoor, R., Ladhak, F., Nazi, A., Huber, M. (2013). Using deep learning to enhance cancer diagnosis and classification, The 30th International Conference on Machine Learning (ICML 2013), WHEALTH workshop, 1-7.

[49] Ibrahim, R., Yousri, N. A., Ismail, M. A., El-Makky, N. M. (2014). Multi-level gene/mirna feature selection using deep belief nets and active learning, 2014 36th Annual International Conference of the IEEE Engineering in Medicine and Biology Society, Chicago, IL, 3957-3960.

[50] Khademi, M., Nedialkov, N. S. (2015). Probabilistic graphical models and deep belief networks for prognosis of breast cancer, 2015 IEEE 14th International Conference on Machine Learning and Applications (ICMLA), Miami, FL, 727-732.

[51] Quang, D., Chen, Y., Xie, X. (2014). Dann: a deep learning approach for annotating the pathogenicity of genetic variants, Bioinformatics, 31, 761-763.

[52] Ramsundar, B., Kearnes, S., Riley, P., Webster, D., Konerding, D., Pande, V. (2015). Massively multitask networks for drug discovery, arXiv:1502.02072.

[53] Zhang, S. et al. (2016). A deep learning framework for modeling structural features of rna-binding protein targets, Nucleic Acids Res, 44(4), e32.

[54] Tian, K., Shao, M., Wang, Y., Zhou, S., Guan, J. (2016). Boosting compound-protein interaction prediction by deep learning, Methods, 110, 64-72.

[55] Angermueller, A., Lee, H., Reik, W., Stegle, O. (2017). Accurate prediction of single-cell dna methylation states using deep learning, Genome Biology, 18(1), 67.

[56] Shan, J., Li, L. (2016). A deep learning method for microaneurysm detection in fundus images, 2016 IEEE First International Conference on Connected Health: Applications, Systems and Engineering Technologies (CHASE), Washington, DC, 357-358.

[57] Mansoor A. et al. (2016). Deep learning guided partitioned shape model for anterior visual pathway segmentation, IEEE Trans. Med. Imag, 35(8): 1856-1865.

[58] Nie, D., Zhang, H., Adeli, E., Liu, L., Shen, D. (2016). 3d deep learning for multi-modal imaging-guided survival time prediction of brain tumor patients, in Proc. MICCAI, 2016, Lecture Notes in Computer Science, 9901, 212-220.

[59] Kleesiek, J. et al. (2016). Deep mri brain extraction: a 3d convolutional neural network for skull stripping, NeuroImage, 129, $460-469$.

[60] Jiang, B., Wang, X., Luo, J., Zhang, X., Xiong, Y., Pang, H. (2015). Convolutional neural networks in automatic recognition of trans-differentiated neural progenitor cells under bright-field microscopy, 2015 Fifth International Conference on Instrumentation and Measurement, Computer, Communication and Control (IMCCC), Qinhuangdao, 122-126.

[61] Havaei, M., Guizard, N., Larochelle, H., Jodoin, P. (2016). Deep learning trends for focal brain pathology segmentation in mri, Machine Learning for Health Informatics, Springer, 25-148.

[62] Suk, H. I. et al. (2014). Hierarchical feature representation and multimodal fusion with deep learning for ad/mci diagnosis, NeuroImage, 101, 569-582.

[63] Kuang, D., He, L. (2014). Classification on adhd with deep learning”, 2014 International Conference on Cloud Computing and Big Data, Wuhan, 27-32. 
[64] Li, F., Tran, L., Thung, K.H., Ji, S., Shen, D., Li, J. (2015). A robust deep model for improved classification of ad/mci patients", IEEE J. Biomed. Health Inform. 9(5), 1610-1616.

[65] Fritscher, K., Raudaschl, P., Zaffino, P., Spadea, M. F., Sharp, G. C., Schubert, R. (2016). Deep neural networks for fast segmentation of 3d medical images, Medical Image Computing and Computer-Assisted Intervention - MICCAI 2016. MICCAI 2016, Lecture Notes in Computer Science, Springer, Cam, 9901, 158-165.

[66] Zhen, X., Wang, Z., Islam, A., Bhaduri, M., Chan, I., Li, S. (2016). Multi-scale deep networks and regression forests for direct bi-ventricular belief estimation, Med. Image Anal., 30, 120-129.

[67] Brosch, T., Tam, R. (2013). Manifold learning of brain mris by deep learning, Medical Image Computing and Computer-Assisted Intervention - MICCAI 2013. Lecture Notes in Computer Science, Springer, Berlin, Heidelberg, 8150, 633-640.

[68] Xu, T., Zhang, H., Huang, X., Zhang, S., Metaxas, D. N. (2016). Multimodal deep learning for cervical dysplasia diagnosis, Medical Image Computing and Computer-Assisted Intervention - MICCAI 2016, Springer, 115-123.

[69] Avendi, M., Kheradvar, A., Jafarkhani, H. (2016). Acombined deep-learning and deformable-model approach to fully automatic segmentation of the left ventricle in cardiac mri, Med. Image Anal., 30, 108-119.

[70] Yu, J., Chen, J., Xiang, Z. Q., Zou, Y. (2015). A hybrid convolutional neural networks with extreme learning machine for WCE image classification, 2015 IEEE International Conference on Robotics and Biomimetics (ROBIO), Zhuhai, $1822-1827$.

[71] Roth, H. R. et al. (2015). Anatomy-specific classification of medical images using deep convolutional nets, 2015 IEEE 12 th International Symposium on Biomedical Imaging (ISBI), New York, NY, 101-104.

[72] Grinsven, M. J. V., Ginneken, B. V., Hoyng, C. B., Theelen, T., S'anchez, C. I. (2016). Fast convolutional neural network training using selective data sampling: Application to hemorrhage detection in color fundus images, IEEE Trans. Med. Imag, 35(5), 1273-1284.

[73] Anthimopoulos, M., Christodoulidis, S., Ebner, L., Christe, A., Mougiakakou, S. (2016). Lung pattern classification for interstitial lung diseases using a deep convolutional neural network, IEEE Trans. Med. Imag., 35(5), $1207-1216$.

[74] Cao, Y. et al. (2016). Improving tuberculosis diagnostics using deep learning and mobile health technologies among resourcepoor and marginalized communities, 2016 IEEE First International Conference on Connected Health: Applications, Systems and Engineering Technologies (CHASE), Washington, DC, 274-281.

[75] Chen, H. et al. (2015). Standard plane localization in fetal ultrasound via domain transferred deep neural networks, IEEE J. Biomed. Health Inform., 19(5), 1627-1636.

[76] Shin, H. C. et al. (2016). Deep convolutional neural networks for computer aided detection: ESA architectures, dataset characteristics and transfer learning, IEEE Trans. Med. Imag., 35(5),1285-1298.

[77] Tajbakhsh, N. et al. (2016). Convolutional neural networks for medical image analysis: full training or fine tuning?, IEEE Trans. Med. Imag., 35(5): 1299-1312.

[78] Yan, Z. et al. (2016). Multi-instance deep learning: Discover discriminative local anatomies for bodypart recognition, IEEE Trans. Med. Imag., 35(5), 1332-1343.

[79] Greenspan, H., Ginneken, B. V., Summers, R. M. (2016). Guest editorial deep learning in medical imaging: overview and future promise of an exciting new technique", IEEE Trans. Med. Imag, 35(5), 1153-1159.

[80] Cheng, J. Z. et al (2016). Computer-aided diagnosis with deep learning architecture: applications to breast lesions in us images and pulmonary nodules in ct scans", Sci. Rep, 6, 24454.

[81] Kondo, T., Ueno, J., Takao, S. (2014). Medical image recognition of abdominal multi-organs by hybrid multi-layered gmdh-type neural network using principal component-regression analysis, 2014 Second International Symposium on Computing and Networking, Shizuoka, 157-163.

[82] Kondo, T., Junji, U., Takao, S. (2014). Hybrid feedback gmdh-type neural network using principal component-regression analysis and its application to medical image recognition of heart regions, 2014 Joint 7th International Conference on Soft Computing and Intelligent Systems (SCIS) and 15th International Symposium on Advanced Intelligent Systems (ISIS), Kitakyushu, 1203-1208.

[83] Kondo, T., Takao, S., Ueno, J. (2015). The 3-dimensional medical image recognition of right and left kidneys by deep gmdh-type neural network, 2015 International Conference on Intelligent Informatics and Biomedical Sciences (ICIIBMS), Okinawa, 313320 .

[84] Kondo, T., Ueno, J., Takao, S. (2016). Medical image diagnosis of lung cancer by deep feedback gmdh-type neural network, Robot. Netw. Artif. Life, 2(4), 252-257.

[85] Rose, D. C., Arel, I., Karnowski, T.P., Paquit, V. C. (2010). Applying deep-layered clustering to mammography image analytics, 2010 Biomedical Sciences and Engineering Conference, Oak Ridge, TN, 1-4.

[86] Zhou, Y., Wei, Y. (2016). Learning hierarchical spectral-spatial features for hyperspectral image classification, IEEE Trans. Cybern, 46(7), 1667-1678.

[87] Lerouge, J., Herault, R., Chatelain, C., Jardin, F., Modzelewski, R. (2015). Ioda: an input/output deep architecture for image labeling, Pattern Recognit., 48(9), 2847-2858.

[88] Wang, J., MacKenzie, J. D., Ramachandran, R., Chen, D. Z. (2016). A deep learning approach for semantic segmentation in histology tissue images, Medical Image Computing and Computer-Assisted Intervention - MICCAI 2016, Springer, $176-184$.

[89] Che, Z., Purushotham, S., Khemani, R., Liu, Y. (2015). Distilling knowledge from deep networks with applications to healthcare domain, NIPS Workshop on Machine Learning for Healthcare (NIPS-MLHC),1-13.

[90] Miotto, R., Li, L., Kidd, B. A., Dudley, J. T. (2016). Deep patient: an unsupervised representation to predict the future of patients from the electronic health records, Sci. Rep., 6, 1-10.

[91] Nie, L., Wang, M., Zhang, L., Yan, S., Zhang, B., Chua, T. S. (2015). Disease inference from health-related questions via sparse deep learning, IEEE Trans. Knowl. Data Eng, 27(8), 2107-2119. 
[92] Mehrabi, S. et al. (2015). Temporal pattern and association discovery of diagnosis codes using deep learning, 2015 International Conference on Healthcare Informatics, Dallas, TX, 408-416.

[93] Shin, H., Lu, L., Kim, L., Seff, A., Yao, J., Summers, R. M. (2016). Interleaved text/image deep mining on a large-scale radiology database for automated image interpretation, JMLR 2016, 17(107), 1-31.

[94] Lipton, Z. C., Kale, D. C., Elkan, C., Wetzel, R. C. (2016). Learning to diagnose with lstm recurrent neural networks, 4th International Conference on Learning Representations, ICLR 2016, San Juan, Puerto Rico, May 2-4.

[95] Liang, Z., Zhang, G., Huang, J. X., Hu, Q. V. (2014). Deep learning for healthcare decision making with EMRs, 2014 IEEE International Conference on Bioinformatics and Biomedicine (BIBM), Belfast, 556-559.

[96] Putin, E. et al. (2016). Deep biomarkers of human aging: application of deep neural networks to biomarker development, Aging, 8, 1021-33.

[97] Futoma, J., Morris, J., Lucas, J. (2015). A comparison of models for predicting early hospital readmissions, Journal of Biomedical Informatics, 56, 229-238.

[98] Zhao, A., Qi, L., Li, J., Dong, J.,Yu, H. (2018). A hybrid spatio-temporal model for detection and severity rating of parkinson's disease from gait data, Neurocomputing, 315, 1-8.

[99] Purushotham, S., Meng, C., Che, Z., Liu, Y. (2018). Benchmarking deep learning models on large healthcare datasets, Journal of Biomedical Informatics, 83: 112-134.

[100] Davoodi, R., Moradi, M. H. (2018). Mortality prediction in intensive care units (icus) using a deep rule-based fuzzy classifier, Journal of Biomedical Informatics, 79, 48-59.

[101] Supratak A. et al. (2016). Survey on feature extraction and applications of biosignals, Editor: Holzinger A., "Machine learning for health informatics", 161-182, Springer International Publishing AG.

[102] Pereira, C. R., Pereira, D. R., Rosa, G. H., Albuquerque, V H. C., Weber, S. A. T., Hook, C., Papa, J. P. (2018). Handwritten assessment through convolutional neural networks: an application to parkinson's disease identification, Artificial Intelligence in Medicine, 87, 67-77.

[103] Wulsin, D. F., Gupta, J. R., Mani, R., Blanco, J. A., Litt, B. (2011). Modeling electroencephalography waveforms with semisupervised deep belief nets: fast classification and anomaly measurement, Journal of Neural Engineering, 8, 3, 036015.

[104] Hu, C., Ju, R., Shen, Y., Zhou, P., Li, Q. (2016). Clinical decision support for alzheimer's disease based on deep learning and brain network, 2016 IEEE International Conference on Communications (ICC), Kuala Lumpur, 1-6.

[105] Pang, S., Yu, Z., Orgun, M.A. (2017). A novel end-to-end classifier using domain transferred deep convolutional neural networks for biomedical images, Computer Methods and Programs in Biomedicine,140, 283-293. 